\title{
Circulating Microparticles as Biomarkers of Stroke: A Focus on the Value of Endothelial- and Platelet-derived Microparticles
}

Heba El-Gamal ${ }^{1}$, Aijaz Parray ${ }^{2}$, Fayaz A Mir ${ }^{3}$, Ashfaq Shuaib ${ }^{2,4}$, Abdelali Agouni ${ }^{{ }^{*}}$

\section{Affiliations:}

1. Department of Pharmaceutical Sciences, College of Pharmacy, QU health, Qatar University, P.O. Box 2713, Doha, Qatar

2. The Stroke Program, The Neuroscience Institute, Academic Health System, Hamad Medical Corporation, P.O. Box 3050, Doha, Qatar

3. Interim Translational Research Institute (iTRI), Academic Health System, Hamad Medical Corporation, P.O. Box 3050, Doha, Qatar

4. Department of Medicine (Neurology), University of Alberta, Edmonton, Alberta, T6G 2R3, Canada

* Correspondence should be sent to:

Dr. Abdelali Agouni, Department of Pharmaceutical Sciences, College of Pharmacy, QU health, Qatar University, P.O. Box 2713, Doha, Qatar. Email: aagouni@qu.edu.qa

Running title: Microparticles as biomarkers in stroke 
Conflict of interest disclosure: Authors declare no competing interests.

\section{Funding Statement}

Our research is supported by Qatar University high collaborative grant (QUCG-CPH-2018\2019-

2) and award NPRP-8-1750-3-360 from Qatar National Research Fund (a member of Qatar Foundation) to AA. The statements made herein are solely the responsibility of the authors.

\section{Acknowledgment}

Figure 1 in this article was partly produced by adapting freely available tools from Servier Medical Art (SMART), which are licensed under a Creative Commons Attribution 3.0 Unported License https://creativecommons.org/licenses/by/3.0/

\section{Author's Contributions}

AA conceptualized the idea. AA and HE wrote the manuscript. AP, FAM, and AS contributed to writing selected sections and critically revised the manuscript. AA coordinated the writing up and the submission process. All authors approved the final version for submission. 


\begin{abstract}
Stroke is one of the leading causes of mortality and disability worldwide. Numerous pathophysiological mechanisms involving blood vessels, coagulation and inflammation contribute to the vascular occlusion. Perturbations in these pathways can be detected by numerous methods including changes in endoplasmic membrane remodeling and rearrangement leading to the shedding of microparticles (MPs) from various cellular origins in the blood. MPs are small membrane-derived vesicles that are shed from nearly all cells in the body in resting state or upon stimulation. MPs act as biological messengers to transfer information to adjacent and distant cells regulating thus various biological processes. MPs may be important biomarkers and tools for the identification of the risk and diagnosis of cerebrovascular diseases. Endothelial activation and dysfunction and altered thrombotic responses are two of the main features predisposing to stroke. Endothelial MPs (EMPs) have been recognized as both biomarkers and effectors of endothelial cell activation and injury while platelet-derived MPs (PMPs) carry a strong pro-coagulant potential and are activated in thrombotic states. Therefore, we reviewed here the role of EMPs and PMPs as biomarkers of stroke. Most studies reported high circulating levels of EMPs and PMPs in addition to other cell origins in stoke patients and have been linked to stroke severity, the size of infarction, and prognosis. The identification and quantification of EMPs and PMPs may thus be useful for the diagnosis and management of stroke.
\end{abstract}

Key words: Biomarkers, Stroke, Endothelial microparticles, Platelet microparticles 


\section{Introduction}

Stroke is one of the most devastating neurological disorders and is considered one of the leading causes of long-term acquired disability in adults (Katan \& Luft, 2018). It is considered to be the second main cause of mortality in the world after ischemic heart disease (IHD) (Benjamin et al., 2018; Katan \& Luft, 2018). According to the American Heart Association (AHA) latest statistical update, there were 6.3 million deaths due to cerebrovascular diseases around the world (Benjamin et al., 2018). In addition, the direct and indirect cost of stroke is very high. In the USA (between 2013 and 2014), this cost was around $\$ 40.1$ billion causing thus a major economic burden (Benjamin et al., 2018). Stroke is a very heterogeneous disease and includes several etiologies and subtypes (Amarenco, Bogousslavsky, Caplan, Donnan, \& Hennerici, 2009). Therefore, consistent definitions of clinical stroke and its subtypes is crucial for the proper interpretation of clinical trials and studies aiming to examine incidence, prevalence and mortality of stroke within predefined populations (Sacco et al., 2013). The World Health Organization (WHO) defined stroke in the 1970s as "rapidly developed clinical signs of focal (or global) disturbance of cerebral function, lasting more than 24 hours or leading to death, with no apparent cause other than of vascular origin" (Aho et al., 1980). However, since significant advances have been made in the clinical and radiographic diagnosis of stroke and its mimics, this definition is now considered outdated and does not reflect the heterogeneity and complexity of the disease. Consequently, in 2013, the AHA and the American Stroke Association (ASA) developed an expert consensus document for an updated definition of stroke, taking into account the remarkable advances in brain imaging and its clinical implications on the diagnosis of stroke and its subtypes (Coupland, Thapar, Qureshi, Jenkins, \& Davies, 2017; Sacco et al., 2013). This document summarized different stroke etiologies and enlisted them in a table for a better definition of stroke. 
Stroke can be classified into 2 major types; ischemic ( $\sim 80 \%)$ which is due to cerebral vessels' blockade and hemorrhagic stroke $(\sim 20 \%)$ which is due to brain hemorrhage (Ojaghihaghighi, Vahdati, Mikaeilpour, \& Ramouz, 2017). Each type is further classified into subtypes according to their etiology. Ischemic stroke has been classified according to Trial of ORG 10172 in Acute Stroke Treatment (TOAST) classification into 5 subtypes based on clinical features and other prognostic markers to; large artery atherosclerosis, small vessel occlusion, cardio-embolism, stroke of other determined etiology and stroke of undetermined etiology (Adams et al., 1993). Hemorrhagic stroke is divided into two subtypes based on bleeding location in the brain to; intracerebral hemorrhage (ICH) where bleeding is directly in brain parenchyma or subarachnoid hemorrhage $(\mathrm{SAH})$ where bleeding takes place between arachnoid space and pia matter surrounding the brain (Ojaghihaghighi et al., 2017). However, other classifications are available for both types of stroke as well.

There is no single outcome that can accurately measure and predict post-acute strokes disability and prognosis (Kasner, 2006). Many scales have been developed to measure stroke outcomes including the modified Rankin scale (mRs), the National institutes of Health stroke scale (NIHSS), the Barthel index (BI), the stroke impact scale (SIS) and the Glasgow outcome scale (GOS) (Harrison, McArthur, \& Quinn, 2013; Kasner, 2006). In addition, each scale has its advantages and pitfalls that must be taken into consideration before choosing a certain one (Kasner, 2006).

Early and accurate stroke diagnosis is crucial in patient care in order to adopt the right therapeutic strategies and prevent permanent disabilities (Ojaghihaghighi et al., 2017). For instance, intravenous thrombolysis with recombinant tissue plasminogen activator (rtPA) which is currently the first line drug used for acute ischemic stroke treatment, is believed to be most 
effective when administered within the first few hours of stroke onset (Gumbinger et al., 2014). Various clinical and radiographic tools are used to diagnose stroke (Sacco et al., 2013). Clinical manifestations and findings help clinicians to determine the type of stroke but usually brain imaging is required (Ojaghihaghighi et al., 2017). Computed tomography (CT) and magnetic resonance imaging (MRI) are used to recognize the brain lesion location, shape, size and extent and is helpful to determine the cause of stroke and exclude mimics (Sacco et al., 2013). Blood biomarkers, including S100 calcium binding protein, brain natriuretic peptides and matrix metalloproteinase-9 have also been evaluated in the diagnosis of acute stroke (Jickling \& Sharp, 2011; Sacco et al., 2013). However, these markers lack specificity since they are generated in other diseases that can also affect the blood brain barrier (BBB) (Kim, Moon, \& Bang, 2013). Therefore, it is necessary to explore novel effective biomarkers to be used in the identification of high-risk patients, rapid diagnosis, determining stroke etiology and pathogenesis, predicting drug response and clinical outcomes, for novel drug development and as endpoints in clinical trials (Bang, 2017). Microparticles (MPs), which are small membrane vesicles released from activated cells, are being currently heavily investigated as promising biomarkers and vectors for multiple cerebrovascular disorders including stroke.

The primary purpose of this review is to highlight the emerging role of MPs in cerebrovascular disease and specifically focusing on MPs of endothelial and platelets origins because they reflect, respectively, endothelial activation and thrombotic activity, two major contributors to the pathophysiology of ischemic stroke. We will initially review the current understanding of the roles of MPs and then focus on their importance in the understanding of cerebrovascular disease.

\section{Cell membrane remodeling and microparticles (MPs) release}


Extracellular vesicles (EVs) are submicron, intact membrane-derived vesicles that are released from cells after activation or during apoptosis (Shet, 2008). These vesicles harbor membrane constituents such as phospholipids, integral membranes and receptors as well as cytoplasmic cargo including various proteins, DNA and RNA adopted from their cells of origin (Hargett \& Bauer, 2013; Hugel, Martinez, Kunzelmann, \& Freyssinet, 2005). There are several types of EVs characterized based on their size and formation/release pathways including, MPs, exosomes, oncosomes and apoptotic bodies (Zaborowski, Balaj, Breakefield, \& Lai, 2015). MPs were first discovered in 1967 by Wolf during his ongoing coagulation studies when he observed subcellular coagulant vesicles in platelet-free plasma to which he referred to as "platelet dust" (Wolf, 1967). Subsequently, numerous studies have been conducted to further investigate the structure, biogenesis and functions of these vesicles gradually replacing it by the term MPs (Crawford, 1971; Hargett \& Bauer, 2013; Webber \& Johnson, 1970). Over the past 40 years, the understanding of MPs has tremendously advanced from being viewed as useless cell debris or cellular trash to one of the key cellular players regulating various physiological and pathological processes throughout the body (Hargett \& Bauer, 2013). In 2005, a standard definition for MPs has been proposed by The International and Haemostasis Vascular Biology subcommittee. They described MPs as 0.1-1 micrometer cell-derived vesicles that lack a nucleus or synthetic capacity, may contain cytoskeletal proteins, and expose some quantity of phosphatidylserine on their surfaces (Hargett \& Bauer, 2013).

\section{Mechanisms of MP formation and shedding}

The shedding of MPs from plasma membrane is an essential part of cell membrane remodeling and is thought to be initiated by increased intracellular calcium (Shet, 2008). The phospholipid cell membrane bilayer is well-structured and each of the two leaflets has a specific lipid 
composition. Phospahtidylcholine and sphingomyelin are expressed on the outer leaflet while aminophospholipids [Phosphatidylserine (PS) and phosphatidylethanolamine] are oriented inwards (Hugel et al., 2005). Membrane enzymes; floppase, scramblase and aminophospholipid translocase (flippase) regulate phospholipid movements and maintain this dynamic asymmetry in a steady state. Upon cell stimulation, cytosolic calcium increases which in turn dysregulates membrane enzymatic balance and leads to the collapse of membrane asymmetry and subsequent externalization of PS. In addition, intracellular calcium activates calpain and Rho kinase which together cause cytoskeleton cleavage and rearrangement facilitating thus membrane blebbing as well as activating apoptosis via a caspase 3-mediated pathway. However, it must be noted that other stimuli that cause disruption of membrane integrity can also lead to the formation of MP (Hugel et al., 2005). Moreover, it has been shown that MPs can be released from inactivated platelets without intracellular calcium signaling and it was observed that this mechanism was dependent on $\alpha \mathrm{II} \beta 3$ integrin and cytoskeleton turnover (Cauwenberghs et al., 2006). Therefore, other pathways are also most probably involved in the formation of MPs hence adding to the complexity of the biology of MP formation and release. Further research is required to fully elucidate the mechanisms governing the formation and shedding of MPs from cell membranes.

\section{Properties and characteristics of MPs}

MPs have been found to be present in blood stream of healthy individuals as well as in patients (Berckmans et al., 2001; Martinez, Tesse, Zobairi, \& Andriantsitohaina, 2005). This suggests that MPs can be beneficial; maintaining homeostasis under normal physiological conditions, or deleterious if overproduced or if they carry pathogenic constituents on their surface or in cargo (Hugel et al., 2005). The concept of MPs is interesting as they are considered a circulating storage pool of bioactive molecules that if interpreted correctly can provide valuable insight 
about the body state and can be used as biomarkers for various pathological states (Hugel et al., 2005). Additionally, MPs act as a form of effective intercellular communication system regulating various fundamental biological processes (Hoyer, Nickenig, \& Werner, 2010). Studies have shown that MPs convey biological information by either direct interaction with cell receptors/integrins initiating cell signaling cascades or by direct fusion with effector cells by endocytosis and the subsequent emptying of MPs content (Hargett \& Bauer, 2013). In this sense, MPs can act as a signaling molecules via the expression of different proteins and lipids on their surface such as tissue factor (TF) and PS (Hoyer et al., 2010). Alternatively, MPs have been shown to transfer complete receptor proteins (e.g., CCR5 receptor), mRNA, microRNAs, proteins and even cellular organelles to recipient cells (Deregibus et al., 2007; Hoyer et al., 2010; Mack et al., 2000; Ratajczak et al., 2006). Nevertheless, more studies are required to confirm that molecular material transferred to recipient cells are biologically functional and significantly affecting cellular responses in target cells (Zaborowski et al., 2015). MPs are very heterogeneous and vary widely depending on the stimulus and cell of origin. For example, the release of MPs in vitro can be induced using a plethora of agents and the resulting MPs vary in structure and composition (Herring, McMichael, \& Smith, 2013). For instance, previous studies have shown that in vitro stimulation of human lymphoid CEM $\mathrm{T}$ cell line using two different pharmacological stimuli generated antigenically and functionally different MP populations. When the CEM cell line was stimulated with phytohemagglutinin for $72 \mathrm{~h}$, followed by phorbol12-myristate-13 and actinomycin D for further 24h, generated MPs harbored the morphogen Sonic hedgehog (Shh) and were found to improve endothelial function both in vitro and in vivo (Agouni et al., 2007). However, when the same cell line was stimulated with an apoptotic signal using actinomycin D for 24h, MPs generated failed to express the morphogen Shh and caused a 
deleterious effect on endothelial function both in vitro and in vivo (Mostefai et al., 2008). These studies highlight the importance of the stimulus at the origin of generating MPs in conditioning the antigenic content and biological messages carried out by the shed extracellular vesicles.

\section{Functions of MPs}

MPs are involved in various vital biological functions such as hemostasis, coagulation, inflammation and angiogenesis (Herring et al., 2013). It has been shown that some MPs may have procoagulant activity due to the externalization of PS which acts as a catalytic surface for enzymatic coagulation complexes assembly (Mooberry \& Key, 2016). In addition, some MPs harbor TF on their surface which is considered to be the main initiator of coagulation cascade in the extrinsic pathway (Meziani, Tesse, \& Andriantsitohaina, 2008). Remarkably, one study showed that PMPs have 50 to 100 more procoagulant activity when compared to activated platelets (Sinauridze et al., 2007). Additionally, MPs have been shown to play a role in hemostasis disorders such as Scott Syndrome, hemophilia A and Von Willebrand disease (VWD) (Mooberry \& Key, 2016). There is also evidence showing that MPs may have anticoagulant and fibrinolytic activity as well (Mooberry \& Key, 2016). MPs have been shown to carry TF pathway inhibitor (TFPI) on their surface and to promote the activity of the anticoagulant protein C (Koshiar, Somajo, Norstrom, \& Dahlback, 2014; Kushak et al., 2005; Steppich et al., 2005; Tans et al., 1991). Therefore, the role of MPs in regulating coagulation is complex and depends on the context of their release. Similarly, MPs are involved in inflammation by facilitating the interaction between immune cells, providing a source of aminophospholipids and participating in the release of cytokines (Meziani et al., 2008; Puddu, Puddu, Cravero, Muscari, \& Muscari, 2010). Furthermore, numerous studies have shown that MPs can regulate angiogenesis and

modulate several steps in blood vessels' formation (Martinez \& Andriantsitohaina, 2011). The 
effects of MPs on the vascular system have been investigated intensively as well. Although it has been shown that some MPs have positive effects on endothelial function, many studies demonstrated that MPs can induce endothelial dysfunction (Agouni et al., 2007; Mostefai et al., 2008). Some of the mechanisms by which MPs induce endothelial dysfunction include, reducing nitric oxide (NO) concentration, inducing inflammation, promoting coagulation, altering angiogenesis and apoptosis (Lovren \& Verma, 2013). A cellular MP and its proposed functions on coagulation, angiogenesis, inflammation and vascular function are illustrated in Figure 1.

\section{Challenges with the analysis of MPs in clinical practice}

Given the importance of MPs as potential biomarkers of disease and vectors of biological messages, they have attracted attention from the scientific community; however, various challenges related to the methods of detection and analysis of MPs are hindering the wide application of MPs in clinical use. Such challenges include:

1. Methods to isolate MPs are not fully developed and standardized yet. Most of the current isolation methods allow enrichment rather than separation of EV subtype populations (Zaborowski et al., 2015). Each of the methods available has its pitfalls and there is no standard protocol for MP isolation. For instance, series of ultra-centrifugations yields are means of good separation of EVs; however, it is often contaminated with high molecular weight protein complexes and cannot differentiate between EVs subtypes and cells of origin. Immunoaffinity-based assays provide better enrichment of EV-specific subtypes and provide more homogenous EV profiles but the overall yield is low. Many MPs subtypes share the same CD pattern of expression and therefore, combining multiple markers to exclude possible subpopulation contamination has been used to overcome this 
issue. For example, Simak et al. (Simak, Gelderman, Yu, Wright, \& Baird, 2006) used cell-specific antibodies combinations to ensure the detection of endothelial MPs while making sure to eliminate MPs of platelet, leukocyte or erythrocyte origins (Simak et al., 2006).

2. MP quantification is highly challenging. Maas et al. (Maas et al., 2015) conducted a thorough comparison between three of the most common methods used to quantify MPs namely; nanoparticle tracking analysis (NTA), tunable resistive pulse sensing (tRPS) and flow cytometry and found substantial differences in EVs counts among these techniques. The study also reiterated the importance of proper technical knowledge of the instruments and their settings and its effect on correct data interpretation (Maas et al., 2015).

3. Handling and processing of blood samples is very crucial and may introduce variability when comparing different studies. Aspects of sample collection, including needle size, the use of tourniquet, the use of syringe versus vacutainer and the type of anticoagulant used. In addition, special attention should be given to speeds of centrifugation, number of centrifugations, freeze/thaw cycles and the duration of MPs storage (Shet, 2008).

4. Proper identification of MPs is also very challenging. Arraud et al. (Arraud et al., 2014) conducted an interesting study to examine MPs morphology and size in which they found that MPs (which were mainly of platelet and erythrocyte origins) are spherical and tubular in shape. Although tubular MPs constituted a small percentage, the total membrane surface area was of the same order of magnitude as spherical MPs. In addition, they found that the majority of MPs in their study did not bind Annexin V which is in contrast with the theory that MPs expose PS when they are formed. They have concluded that these MPs might be formed via a mechanism that maintain the membrane 
phospholipid asymmetry such as direct cell fragmentation or breakdown from PS negative tubular MPs (Arraud et al., 2014).

Since not all studies take these challenges into account, especially older ones, it is very hard to compare and analyze findings reported from various studies.

\section{MPs and stroke}

Almost all cell types are capable of producing and shedding MPs (Shet, 2008). Circulating MPs have been shown to be released from platelets, erythrocytes, leukocytes, endothelial cells and smooth muscle cells (Chiva-Blanch et al., 2016). Numerous studies reported elevated levels of MPs in cardiovascular diseases and ischemic disorders (Agouni, Andriantsitohaina, \& Martinez, 2014). MPs have been linked to multiple pathological states including, atherosclerosis, diabetes, myocardial infarction, metabolic syndrome, hypertension, cancer, preeclampsia and sepsis (Herring et al., 2013; Lovren \& Verma, 2013; Meziani et al., 2008).

Several studies are now being conducted to investigate the potential role of MPs in the context of stroke. It was recently reported in a systematic review that circulating MPs from various cell origins increase in ischemic stroke patients (Wang et al., 2018). Since endothelial dysfunction and thrombotic dysregulation are two major contributors to the pathophysiology of stroke, in this

review we focused on the role of endothelial-derived MPs (EMPs), as key biomarkers of endothelial activation and dysfunction, and platelet-derived MPs (PMPs), as biomarkers of thrombotic state, in the development of stroke. We also reviewed their value as biomarkers in the onset and progression of the disease. Surface antigens that characterize EMPs and PMPs and their functions are summarized in Table $\mathbf{1 .}$

\section{Endothelial-derived MPs (EMPs) and stroke}


Endothelial dysfunction is evident early and is recognized as an important initiator of cerebrovascular disease (Lovren \& Verma, 2013). MPs shed from endothelial cells are involved in inflammation, pro-coagulation and angiogenesis and thus are considered as a biomarkers of endothelial cell activation and injury (Martinez et al., 2005). Profiling of EMPs in stroke may provide understanding of the pathogenesis of the disease and reflect its prognosis. Distinct endothelial MPs phenotypes are released depending on the type of stimulus the cells are subjected to. When endothelial cells were activated by tumor necrosis factor (TNF)- $\alpha$ in vitro, $\mathrm{CD} \mathrm{E}^{+}$(E-selectin) MPs were released. E-selectin participate in leukocyte and platelet recruitment and therefore its release is a marker of ongoing inflammation and endothelial activation. On the other hand, apoptotic endothelial cells shed MPs with specific markers such as $\mathrm{CD} 1^{+}$(PECAM-1) and thus used as a marker for apoptosis (Jimenez et al., 2003). EMPs released from activated cells are $\mathrm{CD} 6 \mathrm{E}^{+}$(E-selectin), CD54 ${ }^{+}$(ICAM-1) and CD106 ${ }^{+}$(VCAM1), whereas EMPs released upon apoptosis include CD31 ${ }^{+}$(PECAM-1), CD105 ${ }^{+}$(endoglin), $\mathrm{CD} 146^{+}$(MCAM) and $\mathrm{CD} 144^{+}$(VE-cadherin) (Deng, Wang, \& Zhang, 2017). Despite differences in settings between the different studies reported, some conclusions can be drawn. $\mathrm{CD} \mathrm{E}^{+}$(E-selectin) has been measured in several stroke studies (Chiva-Blanch et al., 2016; Jung et al., 2009; Lackner et al., 2010; Lee et al., 2012; P. Li \& Qin, 2015; Williams, Jauch, Lindsell, \& Campos, 2007). It has been shown that $\mathrm{CD}^{2} \mathrm{E}^{+}$EMPs are increased in ischemic stroke patients when compared to healthy controls and remained high when assessed after 7 and 90 days (Chiva-Blanch et al., 2016). High levels of CD62E $^{+}$EMPs have also been associated with recent ischemic attacks and increased risk of cardiovascular events; however, no association has been found between $\mathrm{CD}^{2} \mathrm{E}^{+}$EMPs and stroke onset or recurrence (Chiva-Blanch et al., 2016; Jung et al., 2009; Lee et al., 2012). Since E-selectin is a member of the adhesion molecule 
family that facilitates inflammatory cells' adhesion and rolling, these findings suggest the following hypotheses. First, high levels of CD62 ${ }^{+}$EMPs without being correlated to the time of stroke onset demonstrate continuous endothelial cell activation. Second, endothelial dysfunction in ischemic stroke is more likely to be due to cell activation rather than apoptosis. Finally, the lack of correlation between $\mathrm{CD} 62 \mathrm{E}^{+}$EMPs and stroke recurrence while its association with cardiovascular events and hospitalization may suggest general endothelial dysfunction rather than pathology of cerebral ischemic origin (Chiva-Blanch et al., 2016; Jung et al., 2009; Lee et al., 2012).

There is some suggestion that changes in EMPs may be used as a biomarker of stroke severity (Chiva-Blanch et al., 2016; Jung et al., 2009; P. Li \& Qin, 2015; Simak et al., 2006). Higher levels of EMPs have been found in patients with moderate/severe stroke versus mild stroke patients. Stroke severity was assessed using NIHSS scores where a score greater than 5 defined moderate/severe stroke while scores less than 5 indicated mild stroke. Li et al. (P. Li \& Qin, 2015) have shown a positive correlation between CD144 (VE-cadherin) EMPs and stroke severity (P. Li \& Qin, 2015). Another study using the same scale found an increase in some EMPs (including $\mathrm{CD} 144^{+}$) in moderate to severe patients compared to mild stroke patients (Simak et al., 2006). Therefore, CD144 ${ }^{+}$EMPs have the potential to be used to assess stroke severity but further evidence is needed to confirm these findings. Additionally, EMPs can also be used in stroke diagnosis and identification of its etiology and subtypes. Simak et al. (Simak et al., 2006) have shown some correlation between EMPs counts $\left(\mathrm{CD} 105^{+}\right.$and $\left.\mathrm{CD} 54^{+}\right)$and brain lesion which can be useful to identify the extent of brain damage (Simak et al., 2006). In addition, Li et al. (P. Li \& Qin, 2015) showed mild correlation between CD62 $\mathrm{E}^{+}$EMPs and OCSP classification which categorizes stroke subtypes according to ischemic lesion location (P. Li \& 
Qin, 2015). Therefore, CD62E ${ }^{+}$EMP values may predict stroke subtypes. Furthermore, the ratio of $\mathrm{CD} 2 \mathrm{E}^{+} / \mathrm{CD} 31^{+}$(E-selectin/PECAM-1) EMPs has been shown to be able to distinguish between the cause of arterial stenosis and whether it is of intracranial or extracranial origin thus providing potential information about stroke etiology (Jung et al., 2009).

EMPs may also be useful in prognosis in patients with subarachnoid hemorrhage (SAH). One study conducted on patients with hemorrhagic stroke caused by SAH showed elevated levels of EMPs positive for CD54 ${ }^{+}$(ICAM-1), CD62E ${ }^{+}$(E-selectin) and CD106 ${ }^{+}$(VCAM-1). Severe SAH may be followed by complications including cerebral vasospasm (CVS) and cerebral infarction attributable to vasospasm (CIV). This study measured EMPs in patients with CVS and CIV and found that only $\mathrm{CD} 105^{+}$(endoglin) EMPs were upregulated. Since endoglin is considered to be a marker of apoptosis, this finding showed that apoptosis may be a cause of endothelial damage in the early onset of CVS following hemorrhagic strokes (Lackner et al., 2010). It is also worth noting that Simak et al. (Simak et al., 2006) have observed a correlation between CD144 ${ }^{+}$(VEcadherin) EMPs and hemorrhagic transformation that occurred in 5 stroke patients during the study identifying it as a potential marker of acute intracerebral hemorrhage (Simak et al., 2006). Further studies are warranted to prove this correlation.

Williams et al. (Williams et al., 2007) conducted a study to evaluate the effectiveness of EMPs as biomarkers to differentiate between stroke patients and stroke mimics (Williams et al., 2007). They measured $\mathrm{CD}^{+} \mathrm{E}^{+}$(E-selectin) EMPs as a marker of endothelial activation and CD31 $1^{+}$ (PECAM) EMPs as a marker of apoptosis in both groups. The ratio of $\mathrm{CD}^{2} \mathrm{E}^{+} / \mathrm{CD} 31^{+}$(Eselectin/PECAM) EMPs was more than 4 in both groups indicating endothelial injury. However, the study showed no difference in EMPs count between stroke and mimic groups questioning the reliability of using EMPs as a marker to discriminate between them. There were some limitations 
in this study including the low NIHSS score (small infarct volume) in stroke patients and the long sample storage time that may have affected the number of EMPs resulting in the underestimation of MP counts (Williams et al., 2007). Further studies may be required to confirm these findings and judge the effectiveness of EMPs as biomarkers in distinguishing between acute stroke and its mimics.

In conclusion, EMPs evaluation studies conducted on stroke patients present a number of potential benefits in clinical settings but require further research. EMPs may potentially be used as biomarkers, provide insights about stroke severity and infarct lesion, differentiate between stroke subtypes and identify etiologies thereby, helping clinicians to make more effective therapeutic decisions. The ability to differentiate between stroke and mimics may also be very useful.

\section{Platelet-derived MPs (PMPs) and stroke}

PMPs are the most abundant MPs circulating in blood (Italiano, Mairuhu, \& Flaumenhaft, 2010). Collection of PMPs requires careful processing because all platelets may not be successfully depleted from samples prior to measuring and thus may cause misinterpretation (Burnouf, Goubran, Chou, Devos, \& Radosevic, 2014). This may be addressed by adding more centrifugation cycles which can decrease the content of platelets to up to $0.02 \%$. PMPs are measured by many ways including physical methods such as flow cytometry and dynamic light scattering (Lawrie, Albanyan, Cardigan, Mackie, \& Harrison, 2009; Shantsila, Montoro-Garcia, Gallego, \& Lip, 2014). Other methods include assays that measure PMPs' procoagulant activity, ELISA assays and proteomics (Burnouf et al., 2014; Capriotti et al., 2013; Osumi et al., 2001). In addition, cellular assays are conducted in vitro to measure the functional impact of PMPs on cell 
proliferation, angiogenesis, inflammation and the release of cytokines (Burnouf et al., 2014). Flow cytometry and ELISA are the most commonly used methods to determine levels of PMPs in clinical trials.

PMPs carry the surface antigens $\mathrm{CD}^{4} 1^{+}$( $\alpha \mathrm{IIb}$ chain) and $\mathrm{CD}^{+} 1^{+}(\beta 3$ integrin) which bind together to form GPIIa/IIb (integrin $\alpha_{\mathrm{IIb}} \beta_{3}$ ) glycoprotein, CD $42 \mathrm{a}^{+}$(GP IX) and CD $42 \mathrm{~b}^{+}$(GP1b $\alpha$ ) which bind together to form (GP)Ib-IX-V complex and $\mathrm{CD}^{+} \mathrm{P}^{+}$(P-selectin). Since atherosclerosis and thrombosis of cranial arteries are amongst the main causes of arterial occlusion and cerebral infarction, studies explored the role of platelets and its activation in stroke (Bivard, Lincz, Maquire, Parsons, \& Levi, 2017; Chen et al., 2015; Chiva-Blanch et al., 2016; Kuriyama et al., 2010; Lackner et al., 2010).

There are conflicting reports on PMPs following acute stroke or response to treatment. This may be attributed to differences in methods of detection. For instance, studies have shown elevated PMPs levels after acute ischemic stroke that remain elevated after antiplatelet therapy. Other studies showed a significant decrease in PMPs following the initiation of antiplatelet medications (Chen et al., 2015; Chiva-Blanch et al., 2016; Kuriyama et al., 2010; Shirafuji, Hamaguchi, \& Kanda, 2008). Similarly, some studies associated elevated PMPs with the acute phase of cerebral infarction while others linked it to the chronic phase (Kuriyama et al., 2010; Shirafuji et al., 2008). Nevertheless, most of the studies showed that there are higher levels of PMPs post-stroke (ischemic and hemorrhagic) which means that PMPs can be used as biomarkers for diagnosis; however, the benefits of measuring PMPs levels for assessing clinical outcomes after antiplatelet therapy remain to be elucidated (Chen et al., 2015; Chiva-Blanch et al., 2016; Kuriyama et al., 2010; Lackner et al., 2010; Pawelczyk, Baj, Chmielewski, Kaczorowska, \& Klimek, 2009; Shirafuji et al., 2008). Measuring PMPs showed a potential benefit in identifying stroke etiology. 
Studies have shown higher levels of PMPs in patients with large artery arteriosclerosis (LAA) and small artery occlusion (SAO) when compared to controls, patients with cardioembolic thrombi and other unidentified etiologies (Chen et al., 2015; Kuriyama et al., 2010). In addition, Chiva-blanch et al. (Chiva-Blanch et al., 2016) showed that there are higher CD62P ${ }^{+}$(P-selectin) PMPs in LAA subtype compared to other stroke etiologies at 90 days but not at onset of stroke (Chiva-Blanch et al., 2016). Furthermore, PMP levels were higher in patients with stenotic lesions of intracranial arteries and thickness of intima media (Kuriyama et al., 2010).

PMPs may be markers of successful treatment following an acute stroke. PMP levels were related to better reperfusion and recanalization outcomes in acute ischemic stroke patients receiving recombinant tissue plasminogen activator (rt-PA) making it a potential candidate to assess recanalization in stroke patients (Bivard et al., 2017). However, it was noted that PMP levels were not related to infarct size and only a weak correlation has been observed between PMP levels and infarct volume in LAA subtype (Chen et al., 2015; Kuriyama et al., 2010). Taken together, PMPs appear to be good biomarkers for stroke diagnosis and determining stroke etiology but subsequent measuring for follow-up purposes needs more standardization for a better identification of the value of PMPs as biomarkers for stroke recurrence and prognosis. PMPs may also be of potential value in determining reperfusion in patients being treated with rtPA.

\section{Clinical utility of MPs in stroke}

Since MPs play pivotal role in the pathophysiology of different diseases, its clinical applications have been widely investigated. One of the approaches is to use MPs to evaluate and monitor therapeutic efficacy (Chen, Li, \& Liu, 2018). For example, some drugs such as statins, aspirin and anti-oxidants have been shown to reduce MPs levels in patients and thus can be used to 
assess treatment effectiveness (Baron, Boulanger, Staels, \& Tailleux, 2012; Bulut, Becker, \& Mugge, 2011; Morel et al., 2003; Suades, Padro, Alonso, Mata, \& Badimon, 2013). Another approach is utilizing MPs characteristics as therapeutic agents. For instance, the ability of some MPs to stimulate the formation of new blood vessels has been shown to induce revascularization and improve mouse kidney function in an ischemia/reperfusion injury model (Ranghino et al., 2012). In addition, as stated earlier, MPs carry genetic material cargo such as DNA, mRNA and microRNA which can be transferred to distal cells (Hugel et al., 2005). Therefore, MPs have the potential to be used in gene therapy or as non-toxic therapeutic delivery tools (Chen et al., 2018). MPs provide the advantage of being non-toxic and stable in blood; however, the effectiveness of the genetic material or drug delivery to target cells is still to be elucidated (Chen et al., 2018). Furthermore, due to MPs coagulant activity especially of platelet-derived MPs, their use as prothrombotic agents has been explored to treat bleeding disorders like thrombocytopenia (Blajchman, 2003; Piccin, Murphy, \& Smith, 2007). Therefore, various functions of MPs could be utilized to provide therapeutic effects. Also, one of the main promising clinical applications of MPs is their use as biomarkers and diagnostic tools. As mentioned earlier, MPs levels vary with many diseases and therefore could be used for diagnosis (Hugel et al., 2005). Researchers tried to investigate changes in circulating MPs patterns of expression that can be distinctive to certain phenotypes of disease (A. Berezin, 2016). For example, studies by Berezin et al. have widely investigated the imbalance between MPs released from apoptotic versus activated endothelial cells, to which has been referred to as "impaired phenotype", to provide predictive scores for heart failure assessment and predicting cardiovascular risks (A. Berezin, 2016; A. E. Berezin, Kremzer, Martovitskaya, Samura, \& Berezina, 2015; A. E. Berezin, Kremzer, Samura, Berezina, \& Kruzliak, 2015). These scores have been shown to provide better predictive values when 
combined with other markers in heart failure patients (A. E. Berezin, Kremzer, Martovitskaya, Berezina, \& Samura, 2015). A similar score has also been used for stroke diagnosis where a ratio between CD62E/CD31 has been used rather than absolute numbers to discriminate between endothelial activation and apoptosis and to identify the site of arterial stenosis (Jimenez et al., 2003; Jung et al., 2009). In the context of stroke, the use of MPs as diagnostic tools could provide potential value given challenges in stroke's diagnosis. Imaging equipments are expensive, not easily available, time consuming and require professional interpretation (Saenger \& Christenson, 2010). Thus, there is a need for novel stroke biomarkers characterized by early and steady release after infarction, improved sensitivity and specificity over current biomarkers that could differentiate between stroke types and stroke mimics (Saenger \& Christenson, 2010). MPs are being investigated as a promising candidate, but their use is faced by some challenges with regards to sample handling and reliable measurement tools as discussed earlier in this review. Nevertheless, as referred in Figure 2, promising fields include the use of MPs to predict severity of infarct, site of injury and differentiate between different phenotypes. In addition, MPs can also be used to monitor therapeutic efficacy and predict survival rates as shown by Bivard et al. (Bivard et al., 2017) relating PMPs with better recanalization outcomes (Bivard et al., 2017). More studies are warranted to confirm MPs value in stroke treatment and diagnosis.

\section{Conclusions}

Normal basal levels of MPs reflect a tightly controlled balance between cell survival, proliferation and death. Based on the nature of the stimulus that causes their release, this balance is shifted to either direction with changes in the levels and composition of MPs and upon which MPs could be good or bad. Given the complexity of MPs functions and roles, it is still a matter

of debate whether they are a cause or a consequence, friends or foes, active participants or 
passive observers. Nevertheless, MPs acting as remarkable biological sensors are very attractive targets for studying and exploring novel and personalized therapeutic strategies. In this review, we reviewed in more detail the roles of EMPs and PMPs in stroke patients (studies are summarized in Table 2). Despite the challenges, EMPs and PMPs could provide potential benefits as biomarkers, diagnostic tools and prediction of stroke severity (promising markers are illustrated in Figure 2). However, standardization of MPs detection and quantification methods is highly required to further confirm and generalize the results. 


\section{References}

Adams, H. P., Jr., Bendixen, B. H., Kappelle, L. J., Biller, J., Love, B. B., Gordon, D. L., \& Marsh, E. E., 3rd. (1993). Classification of subtype of acute ischemic stroke. Definitions for use in a multicenter clinical trial. TOAST. Trial of Org 10172 in Acute Stroke Treatment. Stroke, 24(1), 35-41.

Agouni, A., Andriantsitohaina, R., \& Martinez, M. C. (2014). Microparticles as biomarkers of vascular dysfunction in metabolic syndrome and its individual components. Curr Vasc Pharmacol, 12(3), 483-492.

Agouni, A., Mostefai, H. A., Porro, C., Carusio, N., Favre, J., Richard, V., . . . Andriantsitohaina, R. (2007). Sonic hedgehog carried by microparticles corrects endothelial injury through nitric oxide release. FASEB J, 21(11), 2735-2741. doi:10.1096/fj.07-8079com

Aho, K., Harmsen, P., Hatano, S., Marquardsen, J., Smirnov, V. E., \& Strasser, T. (1980). Cerebrovascular disease in the community: results of a WHO collaborative study. Bull World Health Organ, 58(1), 113-130.

Amarenco, P., Bogousslavsky, J., Caplan, L. R., Donnan, G. A., \& Hennerici, M. G. (2009). Classification of stroke subtypes. Cerebrovasc Dis, 27(5), 493-501. doi:10.1159/000210432

Arraud, N., Linares, R., Tan, S., Gounou, C., Pasquet, J. M., Mornet, S., \& Brisson, A. R. (2014). Extracellular vesicles from blood plasma: determination of their morphology, size, phenotype and concentration. J Thromb Haemost, 12(5), 614627. doi:10.1111/jth.12554

Bang, O. Y. (2017). Advances in biomarker for stroke patients: from marker to regulator. Precis Future Med, 1(1), 32-42. doi:10.23838/pfm.2017.00052

Baron, M., Boulanger, C. M., Staels, B., \& Tailleux, A. (2012). Cell-derived microparticles in atherosclerosis: biomarkers and targets for pharmacological modulation? J Cell Mol Med, 16(7), 1365-1376. doi:10.1111/j.15824934.2011.01486.x

Benjamin, E. J., Virani, S. S., Callaway, C. W., Chamberlain, A. M., Chang, A. R., Cheng, S., . . . Stroke Statistics, S. (2018). Heart Disease and Stroke Statistics2018 Update: A Report From the American Heart Association. Circulation, 137(12), e67-e492. doi:10.1161/CIR.0000000000000558

Berckmans, R. J., Nieuwland, R., Boing, A. N., Romijn, F. P., Hack, C. E., \& Sturk, A. (2001). Cell-derived microparticles circulate in healthy humans and support low grade thrombin generation. Thromb Haemost, 85(4), 639-646.

Berezin, A. (2016). The Clinical Utility of Circulating Microparticles' Measurement in Heart Failure Patients (Vol. 04).

Berezin, A. E., Kremzer, A. A., Martovitskaya, Y. V., Berezina, T. A., \& Samura, T. A. (2015). The utility of biomarker risk prediction score in patients with chronic heart failure. Clin Hypertens, 22, 3. doi:10.1186/s40885-016-0041-1

Berezin, A. E., Kremzer, A. A., Martovitskaya, Y. V., Samura, T. A., \& Berezina, T. A. (2015). The predictive role of circulating microparticles in patients with chronic heart failure. BBA Clin, 3, 18-24. doi:10.1016/j.bbacli.2014.11.006

Berezin, A. E., Kremzer, A. A., Samura, T. A., Berezina, T. A., \& Kruzliak, P. (2015). Impaired immune phenotype of circulating endothelial-derived microparticles in 
patients with metabolic syndrome and diabetes mellitus. J Endocrinol Invest, 38(8), 865-874. doi:10.1007/s40618-015-0273-z

Bivard, A., Lincz, L. F., Maquire, J., Parsons, M., \& Levi, C. (2017). Platelet microparticles: a biomarker for recanalization in rtPA-treated ischemic stroke patients. Ann Clin Transl Neurol, 4(3), 175-179. doi:10.1002/acn3.392

Blajchman, M. A. (2003). Substitutes and alternatives to platelet transfusions in thrombocytopenic patients. J Thromb Haemost, 1(7), 1637-1641.

Bulut, D., Becker, V., \& Mugge, A. (2011). Acetylsalicylate reduces endothelial and platelet-derived microparticles in patients with coronary artery disease. Can $\mathrm{J}$ Physiol Pharmacol, 89(4), 239-244. doi:10.1139/y11-013

Burnouf, T., Goubran, H. A., Chou, M. L., Devos, D., \& Radosevic, M. (2014). Platelet microparticles: detection and assessment of their paradoxical functional roles in disease and regenerative medicine. Blood Rev, 28(4), 155-166. doi:10.1016/j.blre.2014.04.002

Capriotti, A. L., Caruso, G., Cavaliere, C., Piovesana, S., Samperi, R., \& Lagana, A. (2013). Proteomic characterization of human platelet-derived microparticles. Anal Chim Acta, 776, 57-63. doi:10.1016/j.aca.2013.03.023

Cauwenberghs, S., Feijge, M. A., Harper, A. G., Sage, S. O., Curvers, J., \& Heemskerk, J. W. (2006). Shedding of procoagulant microparticles from unstimulated platelets by integrin-mediated destabilization of actin cytoskeleton. FEBS Lett, 580(22), 5313-5320. doi:10.1016/j.febslet.2006.08.082

Chen, Y., Li, G., \& Liu, M. L. (2018). Microvesicles as Emerging Biomarkers and Therapeutic Targets in Cardiometabolic Diseases. Genomics Proteomics Bioinformatics, 16(1), 50-62. doi:10.1016/j.gpb.2017.03.006

Chen, Y., Xiao, Y., Lin, Z., Xiao, X., He, C., Bihl, J. C., . . Chen, Y. (2015). The Role of Circulating Platelets Microparticles and Platelet Parameters in Acute Ischemic Stroke Patients. J Stroke Cerebrovasc Dis, 24(10), 2313-2320. doi:10.1016/j.jstrokecerebrovasdis.2015.06.018

Chiva-Blanch, G., Suades, R., Crespo, J., Pena, E., Padro, T., Jimenez-Xarrie, E., . . . Badimon, L. (2016). Microparticle Shedding from Neural Progenitor Cells and Vascular Compartment Cells Is Increased in Ischemic Stroke. PLoS One, 11(1), e0148176. doi:10.1371/journal.pone.0148176

Coupland, A. P., Thapar, A., Qureshi, M. I., Jenkins, H., \& Davies, A. H. (2017). The definition of stroke. J R Soc Med, 110(1), 9-12. doi:10.1177/0141076816680121

Crawford, N. (1971). The presence of contractile proteins in platelet microparticles isolated from human and animal platelet-free plasma. $\mathrm{Br} \mathrm{J}$ Haematol, 21(1), 5369.

Deng, F., Wang, S., \& Zhang, L. (2017). Endothelial microparticles act as novel diagnostic and therapeutic biomarkers of circulatory hypoxia-related diseases: a literature review. J Cell Mol Med, 21(9), 1698-1710. doi:10.1111/jcmm.13125

Deregibus, M. C., Cantaluppi, V., Calogero, R., Lo lacono, M., Tetta, C., Biancone, L., . . . Camussi, G. (2007). Endothelial progenitor cell derived microvesicles activate an angiogenic program in endothelial cells by a horizontal transfer of mRNA. Blood, 110(7), 2440-2448. doi:10.1182/blood-2007-03-078709 
Fonsatti, E., \& Maio, M. (2004). Highlights on endoglin (CD105): from basic findings towards clinical applications in human cancer. J Transl Med, 2(1), 18. doi:10.1186/1479-5876-2-18

Fullard, J. F. (2004). The role of the platelet glycoprotein Ilb/Illa in thrombosis and haemostasis. Curr Pharm Des, 10(14), 1567-1576.

Gumbinger, C., Reuter, B., Stock, C., Sauer, T., Wietholter, H., Bruder, I., . . . Schlaganfall, A. G. (2014). Time to treatment with recombinant tissue plasminogen activator and outcome of stroke in clinical practice: retrospective analysis of hospital quality assurance data with comparison with results from randomised clinical trials. BMJ, 348, g3429. doi:10.1136/bmj.g3429

Hargett, L. A., \& Bauer, N. N. (2013). On the origin of microparticles: From "platelet dust" to mediators of intercellular communication. Pulm Circ, 3(2), 329-340. doi:10.4103/2045-8932.114760

Harrison, J. K., McArthur, K. S., \& Quinn, T. J. (2013). Assessment scales in stroke: clinimetric and clinical considerations. Clin Interv Aging, 8, 201-211. doi:10.2147/CIA.S32405

Herring, J. M., McMichael, M. A., \& Smith, S. A. (2013). Microparticles in health and disease. J Vet Intern Med, 27(5), 1020-1033. doi:10.1111/jvim.12128

Hoyer, F. F., Nickenig, G., \& Werner, N. (2010). Microparticles--messengers of biological information. J Cell Mol Med, 14(9), 2250-2256. doi:10.1111/j.15824934.2010.01114.x

Hugel, B., Martinez, M. C., Kunzelmann, C., \& Freyssinet, J. M. (2005). Membrane microparticles: two sides of the coin. Physiology (Bethesda), 20, 22-27. doi:10.1152/physiol.00029.2004

Italiano, J. E., Jr., Mairuhu, A. T., \& Flaumenhaft, R. (2010). Clinical relevance of microparticles from platelets and megakaryocytes. Curr Opin Hematol, 17(6), 578-584. doi:10.1097/MOH.0b013e32833e77ee

Jickling, G. C., \& Sharp, F. R. (2011). Blood biomarkers of ischemic stroke. Neurotherapeutics, 8(3), 349-360. doi:10.1007/s13311-011-0050-4

Jimenez, J. J., Jy, W., Mauro, L. M., Soderland, C., Horstman, L. L., \& Ahn, Y. S. (2003). Endothelial cells release phenotypically and quantitatively distinct microparticles in activation and apoptosis. Thromb Res, 109(4), 175-180.

Jung, K. H., Chu, K., Lee, S. T., Park, H. K., Bahn, J. J., Kim, D. H., . . Roh, J. K. (2009). Circulating endothelial microparticles as a marker of cerebrovascular disease. Ann Neurol, 66(2), 191-199. doi:10.1002/ana.21681

Kasner, S. E. (2006). Clinical interpretation and use of stroke scales. Lancet Neurol, 5(7), 603-612. doi:10.1016/S1474-4422(06)70495-1

Katan, M., \& Luft, A. (2018). Global Burden of Stroke. Semin Neurol, 38(2), 208-211. doi:10.1055/s-0038-1649503

Kim, S. J., Moon, G. J., \& Bang, O. Y. (2013). Biomarkers for stroke. J Stroke, 15(1), 27-37. doi:10.5853/jos.2013.15.1.27

Koedam, J. A., Cramer, E. M., Briend, E., Furie, B., Furie, B. C., \& Wagner, D. D. (1992). P-selectin, a granule membrane protein of platelets and endothelial cells, follows the regulated secretory pathway in AtT-20 cells. J Cell Biol, 116(3), 617625. 
Koshiar, R. L., Somajo, S., Norstrom, E., \& Dahlback, B. (2014). Erythrocyte-derived microparticles supporting activated protein C-mediated regulation of blood coagulation. PLoS One, 9(8), e104200. doi:10.1371/journal.pone.0104200

Kuriyama, N., Nagakane, Y., Hosomi, A., Ohara, T., Kasai, T., Harada, S., . . . Nakagawa, M. (2010). Evaluation of factors associated with elevated levels of platelet-derived microparticles in the acute phase of cerebral infarction. Clin Appl Thromb Hemost, 16(1), 26-32. doi:10.1177/1076029609338047

Kushak, R. I., Nestoridi, E., Lambert, J., Selig, M. K., Ingelfinger, J. R., \& Grabowski, E. F. (2005). Detached endothelial cells and microparticles as sources of tissue factor activity. Thromb Res, 116(5), 409-419. doi:10.1016/j.thromres.2005.01.013

Lackner, P., Dietmann, A., Beer, R., Fischer, M., Broessner, G., Helbok, R., . . . Schmutzhard, E. (2010). Cellular microparticles as a marker for cerebral vasospasm in spontaneous subarachnoid hemorrhage. Stroke, 41(10), 23532357. doi:10.1161/STROKEAHA.110.584995

Lawrie, A. S., Albanyan, A., Cardigan, R. A., Mackie, I. J., \& Harrison, P. (2009). Microparticle sizing by dynamic light scattering in fresh-frozen plasma. Vox Sang, 96(3), 206-212. doi:10.1111/j.1423-0410.2008.01151.x

Lee, S. T., Chu, K., Jung, K. H., Kim, J. M., Moon, H. J., Bahn, J. J., . . Roh, J. K. (2012). Circulating CD62E+ microparticles and cardiovascular outcomes. PLoS One, 7(4), e35713. doi:10.1371/journal.pone.0035713

Ley, K., \& Huo, Y. (2001). VCAM-1 is critical in atherosclerosis. J Clin Invest, 107(10), 1209-1210. doi:10.1172/JCl13005

Li, P., \& Qin, C. (2015). Elevated circulating VE-cadherin+CD144+endothelial microparticles in ischemic cerebrovascular disease. Thromb Res, 135(2), 375381. doi:10.1016/j.thromres.2014.12.006

$\mathrm{Li}, \mathrm{R} .$, \& Emsley, J. (2013). The organizing principle of the platelet glycoprotein Ib-IX-V complex. J Thromb Haemost, 11(4), 605-614. doi:10.1111/jth.12144

Lovren, F., \& Verma, S. (2013). Evolving role of microparticles in the pathophysiology of endothelial dysfunction. Clin Chem, 59(8), 1166-1174. doi:10.1373/clinchem.2012.199711

Maas, S. L., de Vrij, J., van der Vlist, E. J., Geragousian, B., van Bloois, L., Mastrobattista, E., . . . Nolte-'t Hoen, E. N. (2015). Possibilities and limitations of current technologies for quantification of biological extracellular vesicles and synthetic mimics. J Control Release, 200, 87-96. doi:10.1016/j.jconrel.2014.12.041

Mack, M., Kleinschmidt, A., Bruhl, H., Klier, C., Nelson, P. J., Cihak, J., . . Schlondorff, D. (2000). Transfer of the chemokine receptor CCR5 between cells by membrane-derived microparticles: a mechanism for cellular human immunodeficiency virus 1 infection. Nat Med, 6(7), 769-775. doi:10.1038/77498

Martinez, M. C., \& Andriantsitohaina, R. (2011). Microparticles in angiogenesis: therapeutic potential. Circ Res, 109(1), 110-119. doi:10.1161/CIRCRESAHA.110.233049

Martinez, M. C., Tesse, A., Zobairi, F., \& Andriantsitohaina, R. (2005). Shed membrane microparticles from circulating and vascular cells in regulating vascular function. Am J Physiol Heart Circ Physiol, 288(3), H1004-1009. doi:10.1152/ajpheart.00842.2004 
Meziani, F., Tesse, A., \& Andriantsitohaina, R. (2008). Microparticles are vectors of paradoxical information in vascular cells including the endothelium: role in health and diseases. Pharmacol Rep, 60(1), 75-84.

Mooberry, M. J., \& Key, N. S. (2016). Microparticle analysis in disorders of hemostasis and thrombosis. Cytometry A, 89(2), 111-122. doi:10.1002/cyto.a.22647

Morel, O., Jesel, L., Hugel, B., Douchet, M. P., Zupan, M., Chauvin, M., ... Toti, F. (2003). Protective effects of vitamin C on endothelium damage and platelet activation during myocardial infarction in patients with sustained generation of circulating microparticles. J Thromb Haemost, 1(1), 171-177.

Mostefai, H. A., Agouni, A., Carusio, N., Mastronardi, M. L., Heymes, C., Henrion, D., . . . Martinez, M. C. (2008). Phosphatidylinositol 3-kinase and xanthine oxidase regulate nitric oxide and reactive oxygen species productions by apoptotic lymphocyte microparticles in endothelial cells. J Immunol, 180(7), 5028-5035.

Ojaghihaghighi, S., Vahdati, S. S., Mikaeilpour, A., \& Ramouz, A. (2017). Comparison of neurological clinical manifestation in patients with hemorrhagic and ischemic stroke. World J Emerg Med, 8(1), 34-38. doi:10.5847/wjem.j.19208642.2017.01.006

Osumi, K., Ozeki, Y., Saito, S., Nagamura, Y., Ito, H., Kimura, Y., . . Nomura, S. (2001). Development and assessment of enzyme immunoassay for plateletderived microparticles. Thromb Haemost, 85(2), 326-330.

Pawelczyk, M., Baj, Z., Chmielewski, H., Kaczorowska, B., \& Klimek, A. (2009). The influence of hyperlipidemia on platelet activity markers in patients after ischemic stroke. Cerebrovasc Dis, 27(2), 131-137. doi:10.1159/000177920

Piccin, A., Murphy, W. G., \& Smith, O. P. (2007). Circulating microparticles: pathophysiology and clinical implications. Blood Rev, 21(3), 157-171. doi:10.1016/j.blre.2006.09.001

Puddu, P., Puddu, G. M., Cravero, E., Muscari, S., \& Muscari, A. (2010). The involvement of circulating microparticles in inflammation, coagulation and cardiovascular diseases. Can J Cardiol, 26(4), 140-145.

Ranghino, A., Cantaluppi, V., Grange, C., Vitillo, L., Fop, F., Biancone, L., . . Camussi, G. (2012). Endothelial progenitor cell-derived microvesicles improve neovascularization in a murine model of hindlimb ischemia. Int $\mathrm{J}$ Immunopathol Pharmacol, 25(1), 75-85. doi:10.1177/039463201202500110

Ratajczak, J., Miekus, K., Kucia, M., Zhang, J., Reca, R., Dvorak, P., \& Ratajczak, M. Z. (2006). Embryonic stem cell-derived microvesicles reprogram hematopoietic progenitors: evidence for horizontal transfer of mRNA and protein delivery. Leukemia, 20(5), 847-856. doi:10.1038/sj.leu.2404132

Roebuck, K. A., \& Finnegan, A. (1999). Regulation of intercellular adhesion molecule-1 (CD54) gene expression. J Leukoc Biol, 66(6), 876-888.

Sacco, R. L., Kasner, S. E., Broderick, J. P., Caplan, L. R., Connors, J. J., Culebras, A., ... Metabolism. (2013). An updated definition of stroke for the 21st century: a statement for healthcare professionals from the American Heart Association/American Stroke Association. Stroke, 44(7), 2064-2089. doi:10.1161/STR.0b013e318296aeca 
Saenger, A. K., \& Christenson, R. H. (2010). Stroke biomarkers: progress and challenges for diagnosis, prognosis, differentiation, and treatment. Clin Chem, 56(1), 21-33. doi:10.1373/clinchem.2009.133801

Shantsila, E., Montoro-Garcia, S., Gallego, P., \& Lip, G. Y. (2014). Circulating microparticles: challenges and perspectives of flow cytometric assessment. Thromb Haemost, 111(6), 1009-1014. doi:10.1160/TH13-11-0937

Shet, A. S. (2008). Characterizing blood microparticles: technical aspects and challenges. Vasc Health Risk Manag, 4(4), 769-774.

Shih, I. M. (1999). The role of CD146 (Mel-CAM) in biology and pathology. J Pathol, 189(1), 4-11. doi:10.1002/(SICl)1096-9896(199909)189:1<4::AIDPATH332>3.0.CO;2-P

Shirafuji, T., Hamaguchi, H., \& Kanda, F. (2008). Measurement of platelet-derived microparticle levels in the chronic phase of cerebral infarction using an enzymelinked immunosorbent assay. Kobe J Med Sci, 54(1), E55-61.

Simak, J., Gelderman, M. P., Yu, H., Wright, V., \& Baird, A. E. (2006). Circulating endothelial microparticles in acute ischemic stroke: a link to severity, lesion volume and outcome. J Thromb Haemost, 4(6), 1296-1302. doi:10.1111/j.15387836.2006.01911.x

Sinauridze, E. I., Kireev, D. A., Popenko, N. Y., Pichugin, A. V., Panteleev, M. A., Krymskaya, O. V., \& Ataullakhanov, F. I. (2007). Platelet microparticle membranes have 50 - to 100 -fold higher specific procoagulant activity than activated platelets. Thromb Haemost, 97(3), 425-434.

Steppich, B., Mattisek, C., Sobczyk, D., Kastrati, A., Schomig, A., \& Ott, I. (2005). Tissue factor pathway inhibitor on circulating microparticles in acute myocardial infarction. Thromb Haemost, 93(1), 35-39. doi:10.1160/TH04-06-0393

Suades, R., Padro, T., Alonso, R., Mata, P., \& Badimon, L. (2013). Lipid-lowering therapy with statins reduces microparticle shedding from endothelium, platelets and inflammatory cells. Thromb Haemost, 110(2), 366-377. doi:10.1160/TH1303-0238

Tans, G., Rosing, J., Thomassen, M. C., Heeb, M. J., Zwaal, R. F., \& Griffin, J. H. (1991). Comparison of anticoagulant and procoagulant activities of stimulated platelets and platelet-derived microparticles. Blood, 77(12), 2641-2648.

Vestweber, D. (2008). VE-cadherin: the major endothelial adhesion molecule controlling cellular junctions and blood vessel formation. Arterioscler Thromb Vasc Biol, 28(2), 223-232. doi:10.1161/ATVBAHA.107.158014

Wang, B., Cai, W., Zhang, Z., Zhang, H., Tang, K., Zhang, Q., \& Wang, X. (2018). Circulating microparticles in patients after ischemic stroke: a systematic review and meta-analysis. Rev Neurosci. doi:10.1515/revneuro-2017-0105

Webber, A. J., \& Johnson, S. A. (1970). Platelet participation in blood coagulation aspects of hemostasis. Am J Pathol, 60(1), 19-42.

Williams, J. B., Jauch, E. C., Lindsell, C. J., \& Campos, B. (2007). Endothelial microparticle levels are similar in acute ischemic stroke and stroke mimics due to activation and not apoptosis/necrosis. Acad Emerg Med, 14(8), 685-690. doi:10.1197/j.aem.2007.04.009

Wolf, P. (1967). The nature and significance of platelet products in human plasma. $\mathrm{Br} \mathrm{J}$ Haematol, 13(3), 269-288. 
Woodfin, A., Voisin, M. B., \& Nourshargh, S. (2007). PECAM-1: a multi-functional molecule in inflammation and vascular biology. Arterioscler Thromb Vasc Biol, 27(12), 2514-2523. doi:10.1161/ATVBAHA.107.151456

Zaborowski, M. P., Balaj, L., Breakefield, X. O., \& Lai, C. P. (2015). Extracellular Vesicles: Composition, Biological Relevance, and Methods of Study. Bioscience, 65(8), 783-797. doi:10.1093/biosci/biv084 
Table 1. List of EMP and PMP surface markers according to their cell origins and functions

\begin{tabular}{|c|c|c|c|}
\hline $\begin{array}{l}\text { CD } \\
\text { marker }\end{array}$ & Antigen & Function & Refs \\
\hline \multicolumn{4}{|c|}{ Endothelial-derived MPs (EMPs) } \\
\hline CD62E & E-selectin & $\begin{array}{l}\text { Cell adhesion molecule induced in response to } \\
\text { inflammation and is thought to play a role in } \\
\text { recruiting leukocytes to the sites of injury }\end{array}$ & $\begin{array}{l}\text { (Deng et al., } \\
\text { 2017) }\end{array}$ \\
\hline CD105 & Endoglin & $\begin{array}{l}\text { Part of TGF- } \beta \text { receptor complex. Largely } \\
\text { expressed on endothelial cells and induced during } \\
\text { angiogenesis and inflammation. }\end{array}$ & $\begin{array}{l}\text { (Fonsatti \& } \\
\text { Maio, 2004) }\end{array}$ \\
\hline CD144 & $\begin{array}{l}\text { VE-cadherin } \\
\text { (Vascular } \\
\text { endothelial } \\
\text { cadherin) }\end{array}$ & $\begin{array}{l}\text { Constitutively expressed at endothelial adherence } \\
\text { junctions. It plays a role in controlling vascular } \\
\text { permeability and leukocyte extravasation. }\end{array}$ & $\begin{array}{l}\text { (Vestweber, } \\
2008)\end{array}$ \\
\hline CD31 & $\begin{array}{l}\text { PECAM-1 } \\
\text { (Platelet and } \\
\text { endothelial } \\
\text { cell adhesion } \\
\text { molecule) }\end{array}$ & $\begin{array}{l}\text { It is expressed in most vascular compartment cells. } \\
\text { It is found at cell junctions in endothelial cells and } \\
\text { play various roles in inflammation and vascular } \\
\text { biology. }\end{array}$ & $\begin{array}{l}\text { (Woodfin, } \\
\text { Voisin, \& } \\
\text { Nourshargh, } \\
\text { 2007) }\end{array}$ \\
\hline CD54 & $\begin{array}{l}\text { ICAM-1 } \\
\text { (Intercellular } \\
\text { adhesion } \\
\text { molecule) }\end{array}$ & $\begin{array}{l}\text { It is an inducible cell adhesion protein that plays a } \\
\text { role in leukocyte and endothelium interaction to } \\
\text { regulate vascular permeability. It is also induced in } \\
\text { inflammation and is expressed on a wide range of } \\
\text { immune cells such as monocytes and macrophages. }\end{array}$ & $\begin{array}{l}\text { (Roebuck \& } \\
\text { Finnegan, } \\
\text { 1999) }\end{array}$ \\
\hline CD146 & $\begin{array}{l}\text { MCAM } \\
\text { (melanoma } \\
\text { cell adhesion } \\
\text { molecule) }\end{array}$ & $\begin{array}{l}\text { Adhesion molecule involved in cell signaling, } \\
\text { vascular permeability and immune response. }\end{array}$ & $\begin{array}{l}\text { (Shih, } \\
\text { 1999) }\end{array}$ \\
\hline CD106 & $\begin{array}{l}\text { VCAM-1 } \\
\text { (vascular cell } \\
\text { adhesion } \\
\text { molecule) }\end{array}$ & $\begin{array}{l}\text { It is a transmembrane glycoprotein and is a marker } \\
\text { of endothelial cell activation and induced in } \\
\text { inflammation. }\end{array}$ & $\begin{array}{l}\text { (Ley \& } \\
\text { Huo, 2001) }\end{array}$ \\
\hline \multicolumn{4}{|c|}{ Platelet-derived MPs (EMPs) } \\
\hline $\begin{array}{l}\text { CD41 } \\
\text { CD61 }\end{array}$ & $\begin{array}{l}\alpha \mathrm{IIb} \text { chain } \\
\beta 3 \text { integrin }\end{array}$ & $\begin{array}{l}\text { Bind together to form the glycoprotein GPIIa/IIb } \\
\text { (integrin } \alpha_{\mathrm{II}} \beta_{3} \text { ) which is a member of the integrin } \\
\text { transmembrane family. It is expressed on platelets } \\
\text { and is essential for platelets aggregation. It acts as } \\
\text { a receptor for fibrinogen and vonWillebrand factor } \\
\text { (vWF) to facilitate platelets aggregation and cross } \\
\text { linking. }\end{array}$ & $\begin{array}{l}\text { (Fullard, } \\
\text { 2004) }\end{array}$ \\
\hline $\begin{array}{l}\text { CD42a } \\
\text { CD42b }\end{array}$ & $\begin{array}{l}\text { GP IX } \\
\text { GP1b } \alpha\end{array}$ & $\begin{array}{l}\text { Two membrane glycoproteins that bind together to } \\
\text { form (GP)Ib-IX-V complex. (GP)Ib-IX-V is } \\
\text { expressed on platelets surface and is involved in } \\
\text { thrombosis and acts as a receptor for } v W F \text { and }\end{array}$ & $\begin{array}{l}\text { (R. Li \& } \\
\text { Emsley, } \\
\text { 2013) }\end{array}$ \\
\hline
\end{tabular}




\begin{tabular}{|c|c|c|c|}
\hline & & other molecules such as thrombin. & \\
\hline CD62P & P-selectin & $\begin{array}{l}\text { Also known as Platelet Activation-Dependent } \\
\text { Granule to External Membrane Protein } \\
\text { (PADGEM) or Granule Membrane Protein } 140 \\
\text { (GMP-140). It is a transmembrane glycoprotein } \\
\text { that is expressed by activated platelets and plays a } \\
\text { key role in immune cells adhesion and rolling. }\end{array}$ & $\begin{array}{l}\text { (Koedam et } \\
\text { al., 1992) }\end{array}$ \\
\hline
\end{tabular}


Table 1. Summary of key studies that investigated EMPs and PMPs in stroke patients

\begin{tabular}{|c|c|c|c|c|c|}
\hline Type of stroke & $\begin{array}{l}\text { Time of sample } \\
\text { collection }\end{array}$ & MP marker & Findings & $\begin{array}{l}\text { Strengths and } \\
\text { weaknesses }\end{array}$ & Refs \\
\hline \multicolumn{6}{|c|}{ Endothelial-derived MPs (EMPs) } \\
\hline $\begin{array}{l}\text { Patients with acute } \\
\text { cerebral ischemia } \\
\text { divided into two } \\
\text { groups according to } \\
\text { NIHSS scores: } \\
\text { 1. Mild stroke; } \\
\text { score }<5 \\
\text { 2. Moderate to } \\
\text { severe stroke; } \\
\text { score } \geq 5\end{array}$ & $\begin{array}{l}\text { Median time of } \\
37 \mathrm{~h}(18.5- \\
51.8) \text { after onset } \\
\text { of clinical } \\
\text { symptoms }\end{array}$ & 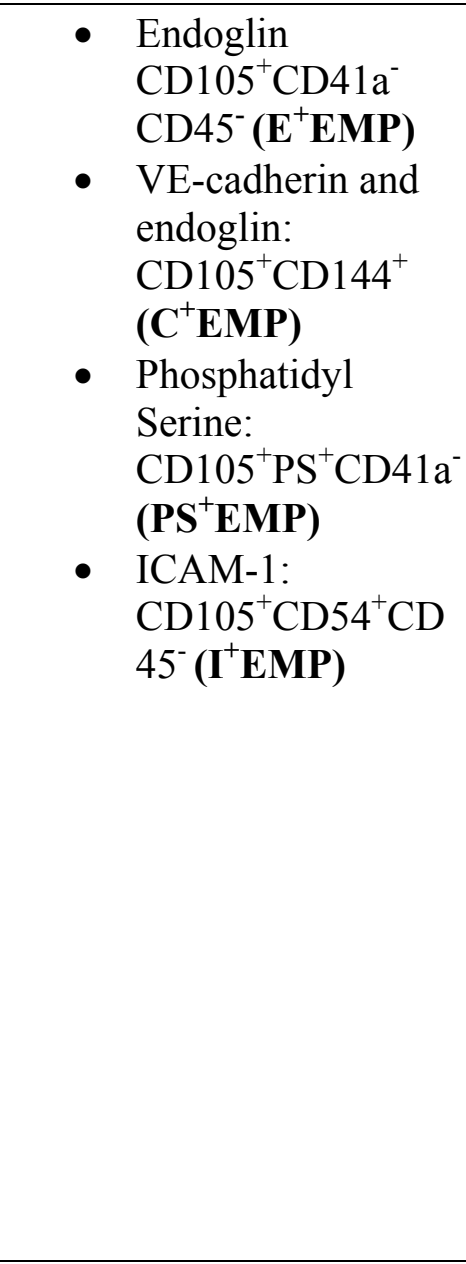 & $\begin{array}{l}\text { - } \text { PS }^{+} \text {EMP were } \\
\text { significantly higher } \\
\text { in all stroke groups } \\
\text { compared to } \\
\text { controls, other } \\
\text { phenotypes } \\
\text { increased but not } \\
\text { significantly } \\
\text { (marker of } \\
\text { procoagulant } \\
\text { endothelium) } \\
\text { C'EMP and I'EMP } \\
\text { levels were also } \\
\text { significantly higher } \\
\text { in the moderate to } \\
\text { severe group } \\
\text { relative to the mild } \\
\text { stroke group } \\
\text { subjects (marker } \\
\text { of stroke severity) } \\
\text { Significant } \\
\text { correlation } \\
\text { between I EMP } \\
\text { (ICAM-1) count } \\
\text { and brain lesion } \\
\text { was observed, less } \\
\end{array}$ & $\begin{array}{l}\text { Strengths: } \\
\text { - The use of } \\
\text { multiple EMP } \\
\text { antigens to avoid } \\
\text { contamination } \\
\text { with MPs of } \\
\text { other origins } \\
\text { - Measuring } \\
\text { markers of } \\
\text { apoptosis and } \\
\text { activation } \\
\text { Weaknesses: } \\
\text { No test has been } \\
\text { made to relate } \\
\text { the increase of } \\
\text { PS EMP with } \\
\text { other } \\
\text { prothrombotic } \\
\text { markers to prove } \\
\text { its role in } \\
\text { procoagulation }\end{array}$ & $\begin{array}{l}\text { (Simak et al., } \\
\text { 2006) }\end{array}$ \\
\hline
\end{tabular}




\begin{tabular}{|c|c|c|c|c|c|}
\hline & & & $\begin{array}{l}\text { correlation with } \\
\mathrm{PS}^{+} \mathrm{EMP}, \mathrm{E}^{+} \mathrm{EMP} \text {. } \\
\text { (marker for } \\
\text { degree of } \\
\text { inflammation and } \\
\text { apoptosis within } \\
\text { ischemic lesion) } \\
\text { - Possible } \\
\text { association } \\
\text { between } \mathrm{C}^{+} \mathrm{EMP} \\
\text { and hemorrhagic } \\
\text { transformation } \\
\text { (diagnosis of } \\
\text { intracerebral } \\
\text { hemorrhage) }\end{array}$ & & \\
\hline $\begin{array}{l}\text { Patients suspected } \\
\text { with ischemic } \\
\text { stroke } v s \text { controls at } \\
\text { high risk of } \\
\text { cardiovascular } \\
\text { disease }\end{array}$ & $\begin{array}{l}\text { - Within } 48 \mathrm{~h} \\
\text { after onset } \\
\text { of stroke }\end{array}$ & $\begin{array}{ll}\text { - } & \text { MCAM: CD146 } \\
\text { - } & \text { E-Selectin:CD62E }\end{array}$ & 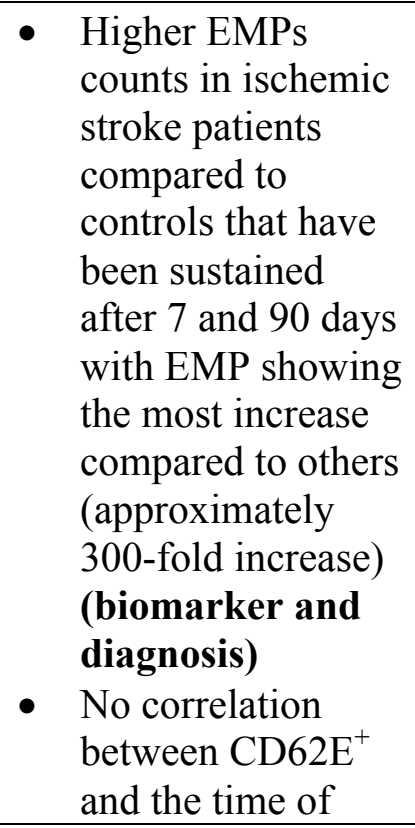 & 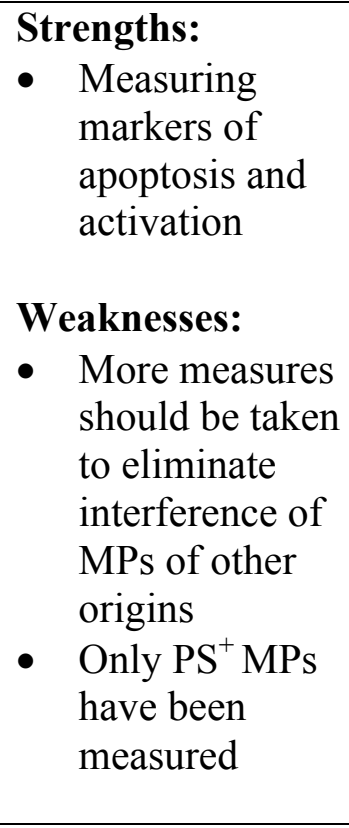 & $\begin{array}{l}\text { (Chiva- } \\
\text { Blanch et al., } \\
\text { 2016) }\end{array}$ \\
\hline
\end{tabular}




\begin{tabular}{|c|c|c|c|c|c|}
\hline & & & \begin{tabular}{|l}
$\begin{array}{l}\text { stroke onset } \\
\text { (continuous cell }\end{array}$ \\
activation) \\
- $\mathrm{CD}^{+} \mathrm{E}^{+}$(marker \\
of activation) more \\
than CD146 \\
(marker of \\
apoptosis) \\
(evidence of \\
selective \\
packaging of \\
MPs) \\
No correlation with \\
lesion volume
\end{tabular} & & \\
\hline $\begin{array}{l}\text { Patients with acute } \\
\text { ischemic stroke } \\
\text { (AIS) vs age- and } \\
\text { sex-matched } \\
\text { healthy controls } \\
\text { Stroke patients } \\
\text { divided into: } \\
\text { 1. Mild stroke; } \\
\text { score }<5 \\
\text { 2. Moderate to } \\
\text { severe stroke; } \\
\text { score } \geq 5\end{array}$ & $\begin{array}{l}\text { Within } 7 \text { days } \\
\text { of the onset of } \\
\text { clinical } \\
\text { symptoms }\end{array}$ & $\begin{array}{ll}\text { - } & \text { VE-cadherin: } \\
& \text { CD144 }{ }^{+} / C D 41 \mathrm{a}^{-} \\
\text {- } & \text { PECAM-1: } \\
& \text { CD31 }{ }^{+} \mathrm{CD} 41 \mathrm{a}^{-} \\
\text {- } & \text { E-Selectin CD62E } \\
\text { - } & \text { E-Selectin PS: } \\
& \mathrm{AV}^{+} \mathrm{CD} 62 \mathrm{E}^{+}\end{array}$ & $\begin{array}{l}\text { - All EMPs } \\
\text { increased in all } \\
\text { acute stroke } \\
\text { patients compared } \\
\text { to controls. All } \\
\text { EMPs were } \\
\text { increased in mild } \\
\text { stroke compared to } \\
\text { controls. Only } \\
\text { EMPs have } \\
\text { increased in } \\
\text { moderate to severe } \\
\text { stroke patients } \\
\text { compared to } \\
\text { controls } \\
\text { (biomarker) } \\
\text { Levels of } \\
\text { CD144 } / \text { CD } 41 \mathrm{a}^{-} \\
\text {(VE-cadherin) }\end{array}$ & 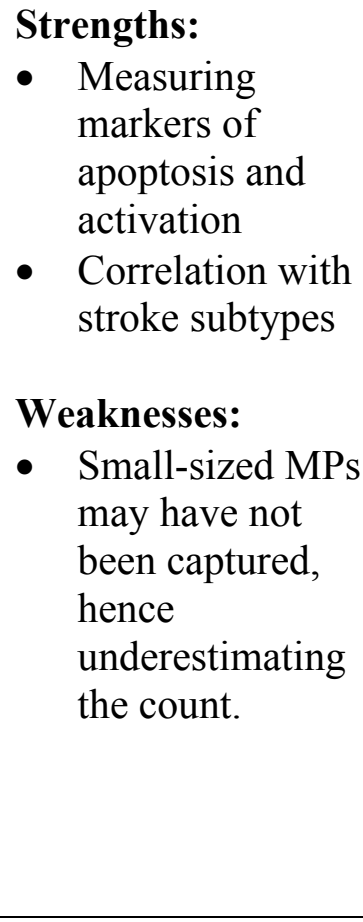 & $\begin{array}{l}\text { (P. Li \& Qin, } \\
2015)\end{array}$ \\
\hline
\end{tabular}




\begin{tabular}{|c|c|c|c|c|c|}
\hline & & & $\begin{array}{l}\text { microparticles } \\
\text { were significantly } \\
\text { correlated with } \\
\text { stroke severity } \\
\text { based on NIHSS } \\
\text { scores (stroke } \\
\text { severity). } \\
\text { - A mild degree of } \\
\text { correlation was } \\
\text { evident between } \\
\text { AV }{ }^{+} \text {CD62E } \\
\text { microparticles and } \\
\text { stroke subtype } \\
\text { based on OCPS } \\
\text { classification } \\
\text { (identification of } \\
\text { stroke subtype). }\end{array}$ & & \\
\hline $\begin{array}{l}\text { Acute stroke } \\
\text { patients } v s \text { patients } \\
\text { with vascular risk } \\
\text { factors but no } \\
\text { stroke events }\end{array}$ & $\begin{array}{l}\text { Within } 7 \text { days } \\
\text { of stroke } \\
\text { symptoms onset }\end{array}$ & $\begin{array}{ll}\text { - } & \text { PECAM-1: } \\
& \mathrm{CD}^{+} 1^{+} / \mathrm{CD} 42 \mathrm{~b}^{-} \\
\text {- } & \mathrm{AV}^{+} \mathrm{PECAM}: \\
& \mathrm{CD} 31^{+} \mathrm{AV}^{+} \\
\text {- } & \text { E-Selectin: CD62E }\end{array}$ & $\begin{array}{l}\text { - Higher levels of } \\
\mathrm{CD}^{+} \mathrm{E}^{+} \text {were } \\
\text { associated with } \\
\text { recent ischemic } \\
\text { attack and } \\
\text { moderate to severe } \\
\text { stroke (biomarker } \\
\text { and severity). } \\
\text { The ratio of } \\
\mathrm{CD} 62 \mathrm{E}^{+} \text {to } \\
\mathrm{CD} 31^{+} / \mathrm{CD} 42 \mathrm{~b}^{-} \text {or } \\
\mathrm{CD} 31^{+} / \mathrm{AV} \mathrm{V}^{+} \mathrm{EMP} \\
\text { levels significantly } \\
\text { discriminated } \\
\text { extracranial and } \\
\text { intracranial arterial }\end{array}$ & $\begin{array}{l}\text { Strengths: } \\
\text { - } \quad \text { Measuring } \\
\text { markers of } \\
\text { apoptosis and } \\
\text { activation } \\
\text { - Correlation with } \\
\text { stroke etiology } \\
\text { Weaknesses: } \\
\text { - No follow-ups } \\
\text { have been } \\
\text { performed }\end{array}$ & $\begin{array}{l}\text { (Jung et al., } \\
2009 \text { ) }\end{array}$ \\
\hline
\end{tabular}




\begin{tabular}{|c|c|c|c|c|c|}
\hline & & & $\begin{array}{l}\text { stenosis (stroke } \\
\text { etiology). }\end{array}$ & & \\
\hline $\begin{array}{l}\text { Patients with stroke } \\
\text { history at least } 3 \\
\text { months prior to } \\
\text { enrollment and } \\
\text { compared to } \\
\text { controls } \\
\text { Patients divided } \\
\text { into: } \\
\text { 1. Low CD62E } \\
\text { MPs group } \\
\text { 2. High CD62 } E^{+} \\
\text {MPs group }\end{array}$ & $\begin{array}{l}\text { At least } 3 \\
\text { months before } \\
\text { enrollment and } \\
\text { followed-up } \\
\text { every } 3 \text { to } 6 \\
\text { months for a } \\
\text { total period of } \\
36 \text { months }\end{array}$ & $\begin{array}{ll}\text { - } & \text { PECAM-1: } \\
& \mathrm{CD}^{+} 1^{+} / \mathrm{CD} 42^{-} \\
\text {- } & \mathrm{AV}^{+} \mathrm{PECAM}: \\
& \mathrm{CD} 31^{+} \mathrm{AV}^{+} \\
\text {- } & \text { E-Selectin: CD62E }\end{array}$ & $\begin{array}{l}\text { - A high level of } \\
\mathrm{CD}_{2} \mathrm{E}^{+} \mathrm{MPs} \text { is } \\
\text { associated with } \\
\text { cardiovascular } \\
\text { events in patients } \\
\text { with stroke history } \\
\text { (prognosis and } \\
\text { identifying high } \\
\text { risk patients) but } \\
\text { not associated with } \\
\text { stroke recurrence. } \\
\text { No association } \\
\text { between } \\
\text { CD31 } \\
\text { cardiovascular } \\
\text { events. }\end{array}$ & $\begin{array}{l}\text { Strengths: } \\
\text { - } \quad \text { Measuring } \\
\text { markers of } \\
\text { apoptosis and } \\
\text { activation } \\
\text { Weaknesses: } \\
\text { - Heterogeneous } \\
\text { patient } \\
\text { population } \\
\text { (including all } \\
\text { types of stroke) } \\
\text { - Few outcome } \\
\text { events measured }\end{array}$ & $\begin{array}{l}\text { (Lee et al., } \\
\text { 2012) }\end{array}$ \\
\hline $\begin{array}{l}\text { Acute ischemic } \\
\text { stroke (AIS) } \\
\text { patients vs mimics }\end{array}$ & $\begin{array}{l}\text { Samples were } \\
\text { collected within } \\
24 \mathrm{~h} \text { of } \\
\text { symptoms onset } \\
\text { and stored for } 1 \text { - } \\
2 \text { years } \\
\text { (prospective } \\
\text { blood banking } \\
\text { project) }\end{array}$ & $\begin{array}{ll}\text { - } & \text { PECAM-1:CD31 } \\
\text { - } & \text { E-selectin: CD62E }\end{array}$ & $\begin{array}{l}\text { EMP levels were } \\
\text { similar in patients } \\
\text { with AIS and } \\
\text { stroke mimic } \\
\text { patients. } \\
\text { The } \\
\text { CD62 } \mathrm{E}^{+} / \mathrm{CD} 31^{+} \\
\text {ratio was more } \\
\text { than } 4 \text { signifying } \\
\text { that EMPs were } \\
\text { generated via } \\
\text { activation and not } \\
\text { apoptosis/necrosis. }\end{array}$ & $\begin{array}{ll}\text { Strengths: } \\
\text { - } & \text { Measuring } \\
& \text { markers of } \\
\text { apoptosis and } & \\
\text { activation } & \\
\text { Weaknesses: } \\
\text { - } & \text { All types of } \\
& \text { stroke patients } \\
\text { were included } & \text { Stroke patients } \\
\text { had low NIHSS } \\
\text { score which }\end{array}$ & $\begin{array}{l}\text { (Williams et } \\
\text { al., 2007) }\end{array}$ \\
\hline
\end{tabular}




\begin{tabular}{|c|c|c|c|c|c|}
\hline & & & $\begin{array}{l}\text { (This suggests } \\
\text { that EMPs may } \\
\text { not be a good } \\
\text { marker for AIS, } \\
\text { given the lack of } \\
\text { ability to } \\
\text { distinguish } \\
\text { between stroke } \\
\text { and its mimics) }\end{array}$ & $\begin{array}{l}\text { means smaller } \\
\text { infarct lesions } \\
\text { therefore, it } \\
\text { might have } \\
\text { caused } \\
\text { underestimation } \\
\text { of EMPs } \\
\text { released } \\
\text { Patient samples } \\
\text { were stored for } \\
1.5 \text { years at - } \\
70^{\circ} \mathrm{C} \text { and } \\
\text { subjected to one } \\
\text { freeze/thaw } \\
\text { cycle which also } \\
\text { might affect } \\
\text { EMPs count }\end{array}$ & \\
\hline $\begin{array}{l}\text { Hemorrhagic stroke } \\
\text { (subarachnoid } \\
\text { hemorrhage SAH) } \\
\text { vs healthy controls }\end{array}$ & $\begin{array}{l}\text { Within } 48 \mathrm{~h} \text { of } \\
\text { stroke onset }\end{array}$ & $\begin{array}{ll}\text { - } & \text { Endoglin: CD105 } \\
\text { - } & \text { VCAM-1: CD } 106^{+} \\
\text {- } & \text { ICAM-1:CD54 } \\
\text { - } & \text { E-Selectin:CD62E }\end{array}$ & $\begin{array}{l}\text { Increased CD54 } \\
\text { (I-CAM), CD62E } \\
\text { (E-selectin) and } \\
\text { CD106 (VCAM- } \\
\text { 1) in SAH } \\
\text { compared to } \\
\text { controls (markers } \\
\text { of endothelial } \\
\text { activation) } \\
\text { Increased CD105 } \\
\text { at early cerebral } \\
\text { vasospasm (CVS) } \\
\text { especially those } \\
\text { with cerebral } \\
\text { infarction } \\
\text { attributable to }\end{array}$ & $\begin{array}{l}\text { Strengths: } \\
\text { - Exploring EMPs } \\
\text { in hemorrhagic } \\
\text { stroke } \\
\text { Weaknesses: } \\
\text { - Low number of } \\
\text { patients }(n=20)\end{array}$ & $\begin{array}{l}\text { (Lackner et } \\
\text { al., 2010) }\end{array}$ \\
\hline
\end{tabular}




\begin{tabular}{|c|c|c|c|c|c|}
\hline & & & $\begin{array}{l}\text { vasospasm (CIV) } \\
\text { (reflects apoptotic } \\
\text { injury) }\end{array}$ & & \\
\hline \multicolumn{6}{|c|}{ Platelet-derived MPs (PMPs) } \\
\hline 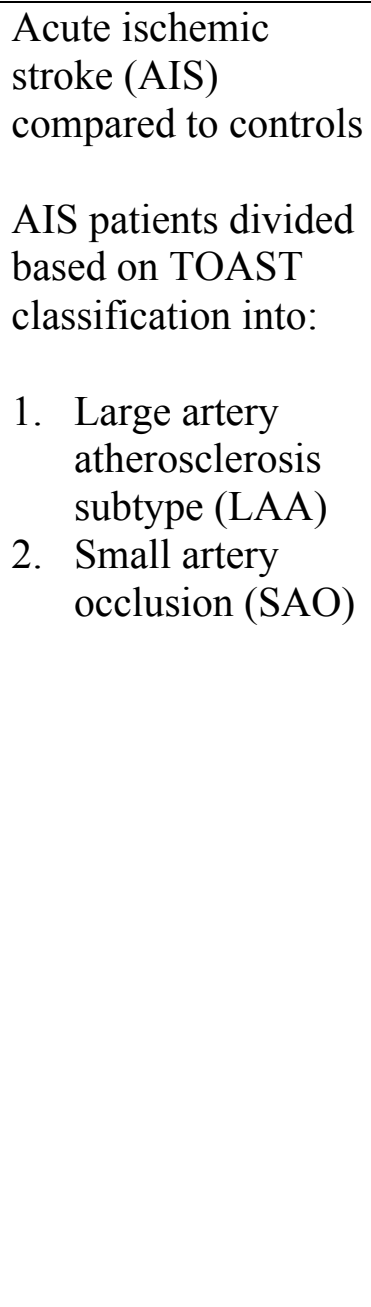 & $\begin{array}{l}\begin{array}{l}\text { After } 48 \mathrm{~h} \\
\text { of stroke } \\
\text { onset }\end{array} \\
\text { - } \begin{array}{l}\text { And after 4- } \\
\text { weeks of } \\
\text { antiplatelet } \\
\text { therapy }\end{array}\end{array}$ & - $\beta 3$ integrin: $\mathrm{CD}^{+} 1^{+}$ & 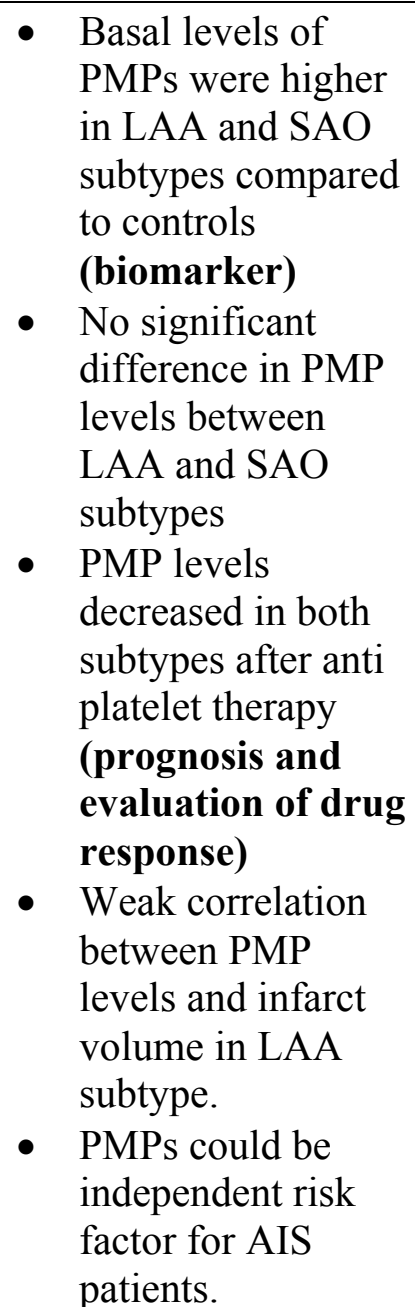 & 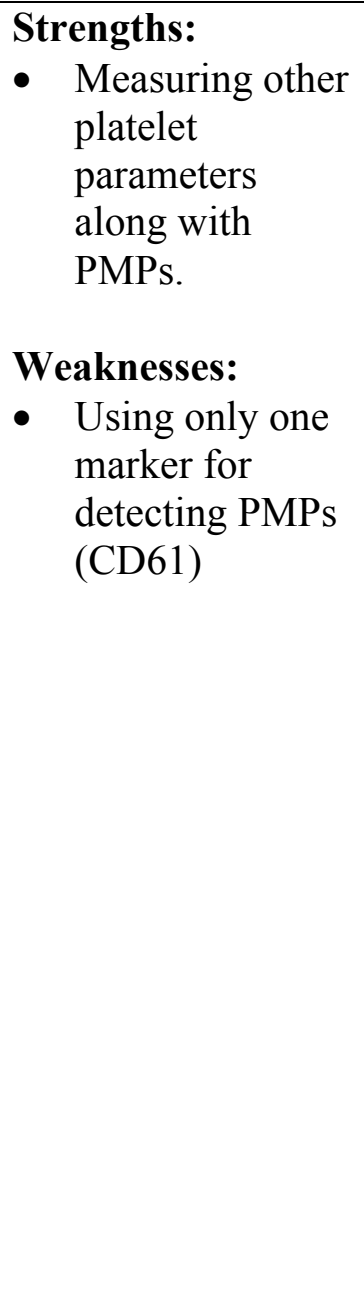 & $\begin{array}{l}\text { (Chen et al., } \\
\text { 2015) }\end{array}$ \\
\hline
\end{tabular}




\begin{tabular}{|c|c|c|c|c|c|}
\hline $\begin{array}{l}\text { Acute ischemic } \\
\text { stroke (AIS) patients } \\
\text { receiving } \\
\text { recombinant tissue } \\
\text { plasminogen } \\
\text { activator (rt-PA) } \\
\text { therapy divided into: } \\
\text { 1. Patients with } \\
\text { recanalization } \\
\text { 2. Patients without } \\
\text { recanalization }\end{array}$ & $\begin{array}{l}\text { After } 24 \mathrm{~h} \text { of } \\
\text { stroke onset }\end{array}$ & - $\quad \alpha I I b$ chain: CD41 $^{+}$ & $\begin{array}{l}\text { - } \mathrm{CD} 41^{+} \text {MPs were } \\
\text { higher in patients } \\
\text { with better } \\
\text { recanalization } \\
\text { outcomes } \\
\text { Total numbers of } \\
\text { CD } 41^{+} \text {related to } \\
\text { reperfusion and } \\
\text { recanalization as } \\
\text { well as } 3 \text { months } \\
\text { mRS. } \\
\text { (assessing clinical } \\
\text { outcomes) }\end{array}$ & $\begin{array}{l}\text { Strengths: } \\
\text { - } \quad \text { Following-up } \\
\text { using mRS to } \\
\text { assess } \\
\text { outcomes } \\
\text { Weaknesses: } \\
\text { - } \text { Single time } \\
\text { point } \\
\text { measurement } \\
\text { (at } 24 \text { h) which } \\
\text { can be affected } \\
\text { by many } \\
\text { factors } \\
\text { No comparison } \\
\text { with pre- } \\
\text { canalization } \\
\text { levels }\end{array}$ & $\begin{array}{l}\text { (Bivard et } \\
\text { al., 2017) }\end{array}$ \\
\hline $\begin{array}{l}\text { Patients suspected } \\
\text { with ischemic stroke } \\
v s \text { controls at high } \\
\text { risk of } \\
\text { cardiovascular } \\
\text { disease }\end{array}$ & $\begin{array}{l}\text { Within } 48 \mathrm{~h} \\
\text { after onset of } \\
\text { stroke } \\
\text { And then after } 7 \\
\text { and } 90 \text { days }\end{array}$ & $\begin{array}{ll}\text { - } & \beta 3 \text { integrin: } \\
& \mathrm{CD}^{+} / \mathrm{AV}^{+} \\
\text {- } & \beta 3 \text { integrin} / \mathrm{TF}: \\
& \mathrm{CD} 61^{+} / \mathrm{CD} 142^{+} / \mathrm{AV}^{+} \\
\text {- } & \text { P-selectin: } \\
& \mathrm{CD} 62 \mathrm{P}^{+} / \mathrm{AV}^{+}\end{array}$ & 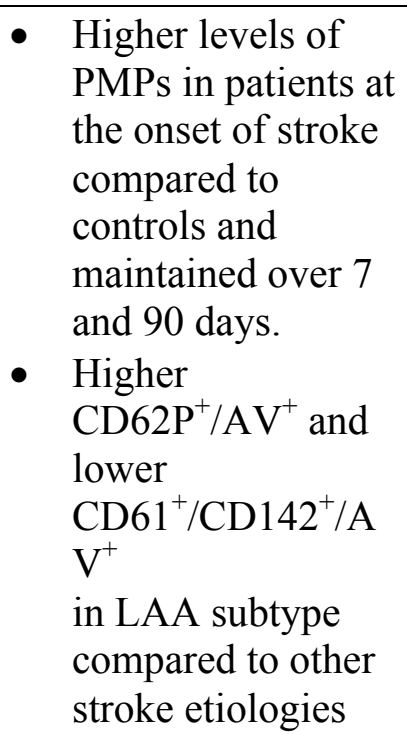 & $\begin{array}{l}\text { Strengths: } \\
\text { - } \quad \begin{array}{l}\text { Measuring } \\
\text { markers of } \\
\text { apoptosis and } \\
\text { activation }\end{array} \\
\text { Weaknesses: } \\
\text { - } \quad \begin{array}{l}\text { More measures } \\
\text { should be taken }\end{array} \\
\text { to eliminate } \\
\text { interference of } \\
\text { MPs of other } \\
\text { origins } \\
\text { Only PS MPs } \\
\text { have been }\end{array}$ & $\begin{array}{l}\text { (Chiva- } \\
\text { Blanch et al., } \\
\text { 2016) }\end{array}$ \\
\hline
\end{tabular}




\begin{tabular}{|c|c|c|c|c|c|}
\hline & & & $\begin{array}{l}\text { (based on TOAST } \\
\text { classification) at } 90 \\
\text { days but not at } \\
\text { onset of stroke. } \\
\text { (etiology) }\end{array}$ & measured & \\
\hline $\begin{array}{l}\text { Hemorrhagic stroke } \\
\text { (subarachnoid } \\
\text { hemorrhage SAH) vs } \\
\text { healthy controls }\end{array}$ & $\begin{array}{l}\text { Within } 48 \mathrm{~h} \text { of } \\
\text { stroke onset }\end{array}$ & $\begin{array}{ll}- & \alpha I I b \text { chain:CD41+ } \\
\text { - } & \alpha I I b \text { chain/ } \\
& \mathrm{A}^{+}: \mathrm{CD} 41+/ \mathrm{A}^{+}\end{array}$ & $\begin{array}{l}\text { Mild increase in } \\
\text { PMPs compared to } \\
\text { controls } \\
\text { (biomarker and } \\
\text { diagnosis) }\end{array}$ & $\begin{array}{l}\text { Strengths: } \\
\text { - Exploring EMPs } \\
\text { in hemorrhagic } \\
\text { stroke } \\
\text { Weaknesses: } \\
\text { - Small number of } \\
\text { patients }(n=20)\end{array}$ & $\begin{array}{l}\text { (Lackner et } \\
\text { al., 2010) }\end{array}$ \\
\hline 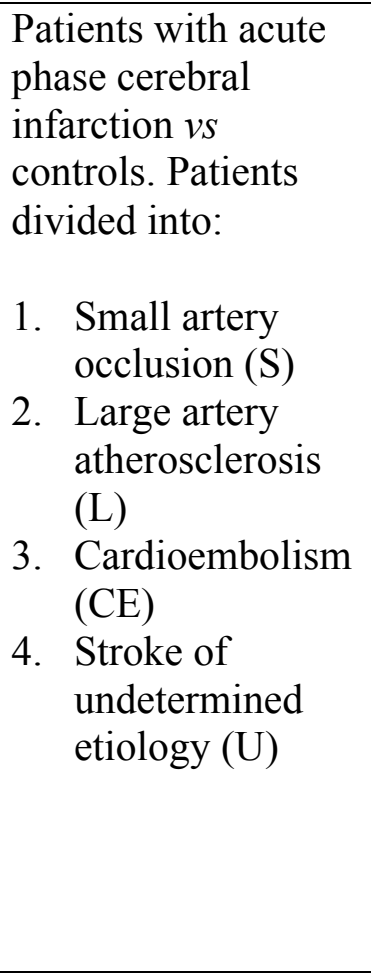 & $\begin{array}{l}\text { Within } 24 \text { h of } \\
\text { stroke onset } \\
\text { After six } \\
\text { months for } 58 \\
\text { patients with } \\
\text { small vessel } \\
\text { occlusion and } \\
\text { large artery } \\
\text { atherosclerosis }\end{array}$ & $\begin{array}{ll}- & \text { GbIb antibody } \\
\text { (ELISA) }\end{array}$ & 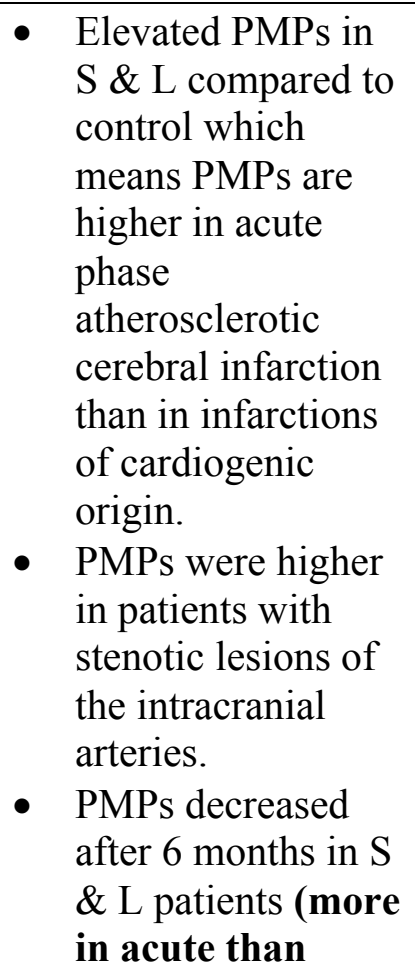 & $\begin{array}{l}\text { Strengths: } \\
\text { - Correlating PMP } \\
\text { levels with } \\
\text { underlying } \\
\text { causes and } \\
\text { coagulation } \\
\text { markers } \\
\text { Weaknesses: } \\
\text { - No follow-up to } \\
\text { check the effect } \\
\text { of decrease in } \\
\text { PMPs on infarct } \\
\text { size and final } \\
\text { outcome }\end{array}$ & $\begin{array}{l}\text { (Kuriyama et } \\
\text { al., 2010) }\end{array}$ \\
\hline
\end{tabular}




\begin{tabular}{|c|c|c|c|c|c|}
\hline & & & $\begin{array}{l}\text { chronic phase) } \\
\text { - No direct relation } \\
\text { between PMPs and } \\
\text { infarct size }\end{array}$ & & \\
\hline $\begin{array}{l}\text { Patients with chronic } \\
\text { phase of cerebral } \\
\text { infarction (more than } \\
3 \text { months) vs } \\
\text { controls }\end{array}$ & $\begin{array}{l}\text { More than } 3 \\
\text { months from } \\
\text { stroke onset }\end{array}$ & - ELISA & $\begin{array}{l}\text { Higher PMP levels } \\
\text { in patients with } \\
\text { chronic cerebral } \\
\text { infarction that have } \\
\text { remained elevated } \\
\text { after antiplatelet } \\
\text { therapy (4-week } \\
\text { course) }\end{array}$ & $\begin{array}{l}\text { Strengths: } \\
\text { - Comparing PMP } \\
\text { levels before and } \\
\text { after antiplatelet } \\
\text { therapy } \\
\text { Weaknesses: } \\
\text { - Small number of } \\
\text { patients }\end{array}$ & $\begin{array}{l}\text { (Shirafuji et } \\
\text { al., 2008) }\end{array}$ \\
\hline
\end{tabular}




\section{Figure Legends}

Figure 1. Structure and functions of MPs. MPs are released from endothelial and platelet cells in resting state and upon stimulation. After membrane rearrangement, MPs externalize phosphatidylserine (PS) and harbor other cell surface molecules from their parent cells such as tissue factor (TF) and adhesion molecules (i.e. integrins, selectins and cadherins). In addition, they carry cargo including proteins, DNA, RNA, microRNAs and cytokines. Based on numerous factors, released MPs may play a role in various biological processes such as coagulation, angiogenesis, inflammation and vascular endothelium function regulation. The figure shows surface antigens expressed by EMPs and PMPs and the major biological processes they are involved in.

Abbreviations: PECAM, Platelet and endothelial cell adhesion molecule; MCAM, melanoma cell adhesion molecule; VCAM-1, vascular cell adhesion molecule; ICAM-1, Intercellular adhesion molecule; VE-cadherin, vascular endothelial cadherin; GP, glycoprotein; MPs, microparticles.

Figure 2. The most promising MP phenotypes for stroke diagnosis. 


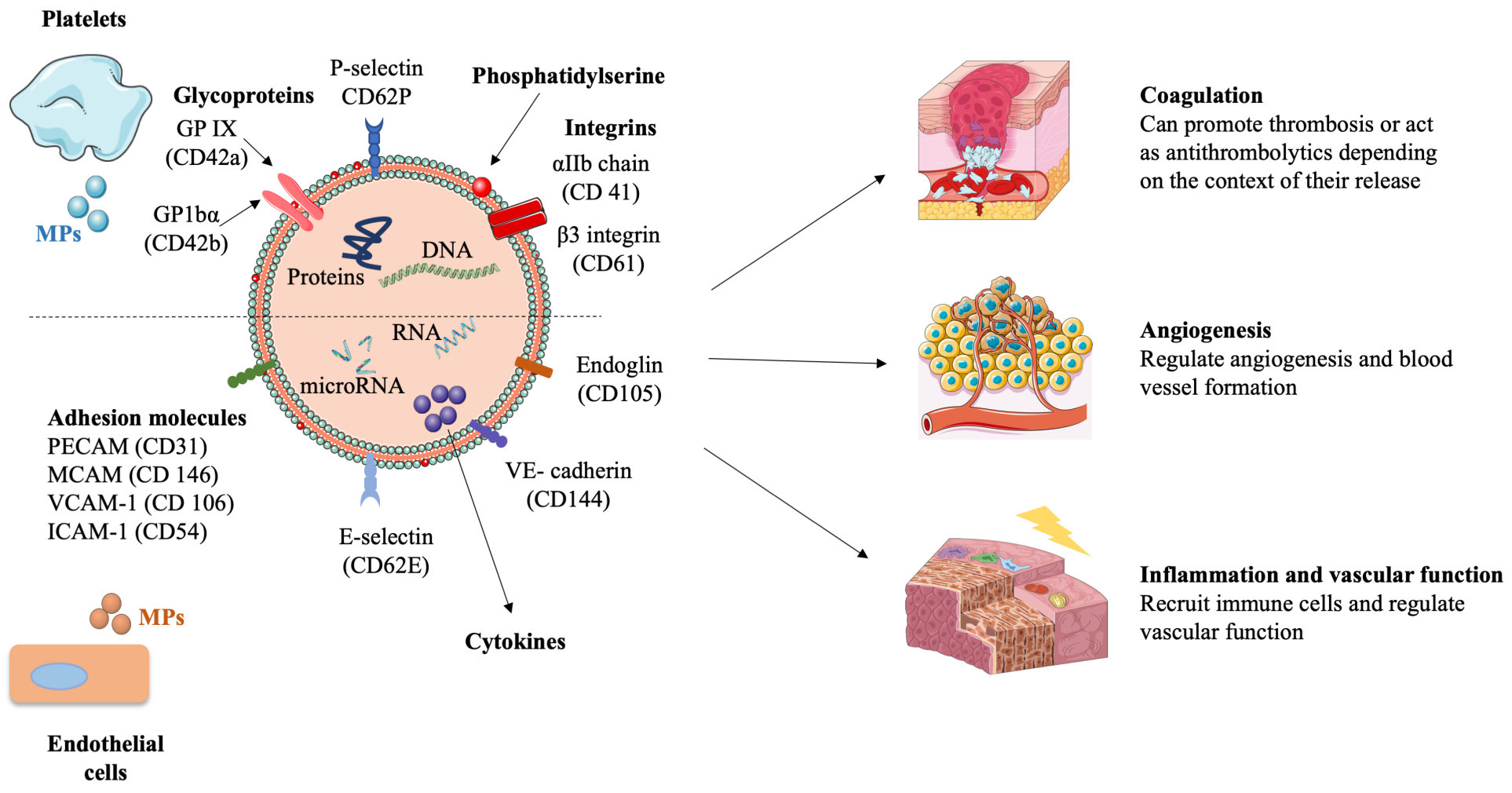

Figure 1. Structure and functions of MPs. MPs are released from endothelial and platelet cells in resting state and upon stimulation. After membrane rearrangement, MPs externalize phosphatidylserine (PS) and harbor other cell surface molecules from their parent cells such as tissue factor (TF) and adhesion molecules (i.e. integrins, selectins and cadherins). In addition, they carry cargo including proteins, DNA, RNA, microRNAs and cytokines. Based on numerous factors, released MPs may play a role in various biological processes such as coagulation, angiogenesis, inflammation and vascular endothelium function regulation. The figure shows surface antigens expressed by EMPs and PMPs and the major biological processes they are involved in. Abbreviations: PECAM, Platelet and endothelial cell adhesion molecule; MCAM, melanoma cell adhesion molecule; VCAM-1, vascular cell adhesion molecule; ICAM-1, Intercellular adhesion molecule; VE-cadherin, vascular endothelial cadherin; GP, glycoprotein; MPs, microparticles. 


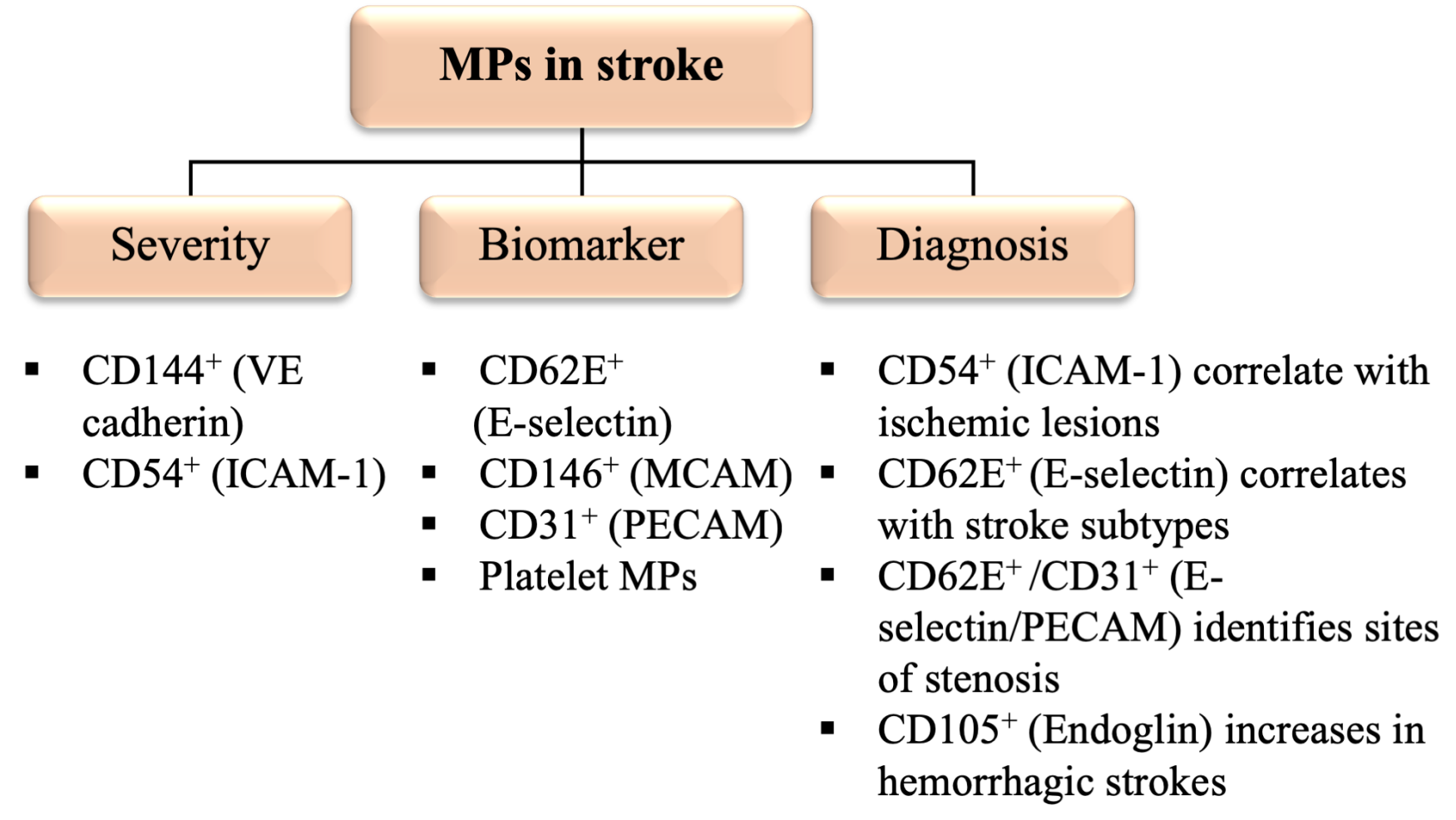

Figure 2. The most promising MP phenotypes for stroke diagnosis. 